Article

\title{
Postcolonial Islam in My Son the Fanatic: From Deobandi Revivalism to the Secular Transposition of the Sufi Imaginary
}

\author{
Jamie S. Scott
}

check for updates

Citation: Scott, Jamie S. Postcolonial Islam in My Son the Fanatic: From Deobandi Revivalism to the Secular Transposition of the Sufi Imaginary. Humanities 2021, 10, 1. https://doi. org/10.3390/h10010001

Received: 28 November 2020 Accepted: 16 December 2020 Published: 23 December 2020

Publisher's Note: MDPI stays neutral with regard to jurisdictional claims in published maps and institutional affiliations.

Copyright: () 2020 by the author. Licensee MDPI, Basel, Switzerland. This article is an open access article distributed under the terms and conditions of the Creative Commons Attribution (CC BY) license (https: / / creativecommons.org / licenses/by/4.0/).
Department of Humanities, York University, Toronto, ON M3J 1P3, Canada; jscott@yorku.ca

\begin{abstract}
Set in the early 1990s, Hanif Kureishi's short story "My Son the Fanatic" (1997) dramatizes tensions between Parvez, a lapsed Pakistani Muslim migrant to postcolonial England, and his son Ali, who rejects the western secularity of his father and reverts to a strict form of fundamentalist Islam. If these tensions remain unresolved in the story, Kureishi's film adaptation elaborates them. In so doing, though, My Son the Fanatic (dir. Udayan Prasad 1997) presents a very different picture. Renamed Farid, the film's eponymous youth breaks off engagement to the daughter of the local chief of police and challenges his father: "Can you put keema [minced meat] with strawberries?" Metaphorically, this question articulates the deeper concern underlying the story: How might migrants in diaspora live an authentic Muslim life in the secular environment of the predominantly non-Muslim United Kingdom? A close reading of My Son the Fanatic reveals vying answers. Farid and Parvez both invoke the Qur'an, ultimate arbiter of value, meaning and truth in Islam, but thence their paths diverge widely. On the one hand, the film depicts the revivalist maslak of Deobandi Islam, though such missionary fervour may lead all too easily to the violent militancy of Farid and his cohort. On the other hand, My Son the Fanatic suggests conditions of possibility for a Muslim life of sacralised secularity by developing the love between Parvez and Sandra in terms of tropes and themes transposed from the Sufi imaginary to the postcolonial United Kingdom, most notably an ethos of $i \grave{s} s \bar{n} n$, that is, the cultivation of what is beautiful and good.
\end{abstract}

Keywords: Hanif Kureishi; My Son the Fanatic; Pakistani diaspora; Deobandi dawa; Sufi ihsān

\section{Introduction}

A snapshot of life in a Muslim diaspora community in London, Hanif Kureishi's short story "My Son the Fanatic" was first published in the The New Yorker in 1994, then republished in 1997 in an anthology titled Love in a Blue Time. Set in the early 1990s, the story dramatizes the process of estrangement between Parvez, a lapsed Muslim immigrant from Lahore, in Pakistan's province of Punjab, and his son Ali, who has "never left England" (Kureishi 1997, p. 128). Dedicated to his son's future well-being, Parvez has worked "long hours" for 20 years as a taxi driver, so that he might provide Ali "good suits ... books ... and a computer" for his "education as an accountant" (Kureishi 1997, p. 119). When Ali breaks up with his "English girlfriend", however, and disposes of such prized material possessions as his guitar and fashionable wardrobe, Parvez worries that his son has become a drug addict (Kureishi 1997, p. 119). He reveals his concern to a sex-worker, Bettina, a regular fare with the street smarts to recognize tell-tale signs of addiction. But Ali betrays no such signs; rather, his sudden change of behavior has to do with reversion to a strict form of conservative Islam.

The friction between father and son comes to a head at dinner in a restaurant. Confiding once again in Bettina, Parvez describes the contretemps. Humiliated by a maulvi as a schoolboy in Pakistan, he explains, he has "avoided all religions" in diaspora (Kureishi 1997, p. 123). Now, though, his son castigates him for breaking "countless rules of the Koran" and pronounces an eschatological judgment on "Western civilisation" (Kureishi 1997, p. 125): 
The Law of Islam would rule the world; the skin of the infidel would burn off again and again; the Jews and Christers would be routed. The West was a sink of hypocrites, adulterers, homosexuals, drug takers and prostitutes. (Kureishi 1997, p. 126)

Anti-Semitic, anti-Christian, homophobic, and otherwise chauvinistic, the youth prophesies the "reward" of a place in "Paradise" for Muslims who pursue jihad against "Western materialists" and dismisses his father's "love" of England's liberal ways as precisely "the problem" (Kureishi 1997, p. 126). Driven thus to drink and tears, Parvez vows to Bettina that he will throw Ali out of the house. Showing more compassion, however, she suggests that "[m]any young men fall into cults and superstitious groups" and encourages Parvez to bear with Ali "until he came through" (Kureishi 1997, p. 128). Persuaded, Parvez seeks some middle ground; he curbs his drinking, starts to grow a halal [religiously permissible] beard and tries to awaken his son to "the beauty of living" (Kureishi 1997, p. 129). These efforts come to naught, but a chance encounter brings together Bettina and Ali in Parvez's taxi. Keen to help, Bettina assures Ali of his father's love, only to be rudely rebuffed by the youth for "inadvertently" touching Parvez on the shoulder (Kureishi 1997, p. 130). Bettina leaves, Parvez and Ali return home, and after several whiskies, Parvez storms into his son's room and kicks and beats him as he prays. Neither defending himself nor retaliating, Ali simply asks his father: "So who's the fanatic now?" (Kureishi 1997, p. 131). It is the last line of the story.

"My Son the Fanatic" thus couches tensions pervading the Pakistani Muslim diaspora community in the United Kingdom in terms of intergenerational estrangement between the newly devout Ali, "a clear example of a fundamentalist", and the ostensibly secular Parvez, "a nominal Muslim who is willing to ignore the ordinances of Islam in order to be able to live in harmony with English culture" (Majed 2015, p. 56). In so doing, however, the short story resolutely refuses resolution. By contrast, a close reading of the film $M y$ Son the Fanatic (1997), also scripted by Kureishi and directed by Udayan Prasad, offers a more nuanced take on such issues. Numerous factors contribute to the picture's greater complexity. Details in the dramatis personae signal the rethink. Parvez (Om Puri) is given the surname Aziz and the story's eponymous youth Ali becomes Farid (Akbar Kurtha). ${ }^{1}$ Bettina (Rachel Griffiths) turns out to be the sex-worker's professional alias in the film; her actual name is Sandra. Important new characters appear, too: Parvez's long-suffering wife, Minoo (Gopi Desai); his cousin Fizzy (Harish Patel), a successful restaurateur; the hedonistic German businessman, Schitz (Stellan Skarsgård); and the earnest, yet naive Pakistani Islamic scholar, or maulvi (Bhasker Patel). Perhaps most significantly, however, Kureishi shifts the action from London to a post-industrial northern location modelled on Bradford, Yorkshire, long the home of the United Kingdom's largest Pakistani diaspora community outside the capital. ${ }^{2}$ "I needed an enclosed community", Kureishi explains to Colin MacCabe, "and I was fascinated-had become fascinated after the Rushdie fatwa-by fundamentalism. ${ }^{3}$ And the arguments between the generations of Asians, the young Asian

1 The screenplay of My Son the Fanatic does not provide Parvez's family name, but the camera focuses a close-up on a "Yorkshire Bank" cheque for "one thousand pounds only" made out to "P. Aziz" by his restauranteur cousin Fizzy (Prasad 1997, pp. 1, 11, 20).

2 As John R. Bowen notes, "the cities of Bradford and Birmingham have the largest settlements of people from Pakistan", who "make up the large majority of Muslim residents of these cities and districts" (Bowen 2016, p. 13).

3 Kureishi's perception of Bradford's Pakistani Muslims as an "enclosed community" reflects a widespread view. "For many Britons", Bowen writes, "a mention of Bradford calls up images of Pakistani-Muslim neighborhoods that have little contact with largely white areas: a segregated city" (Bowen 2016, p. 15). Mention of the "Rushdie fatwa" provides another significant historical touchstone. On 14 February 1989, Iran's Supreme Leader, Ayatollah Ruhollah Khomeini, issued a fatwa, or Islamic legal opinion, enjoining Muslims to kill Salman Rushdie for allegedly blaspheming Muhammad in the novel The Satanic Verses (Rushdie 1988). 
kids being more fundamentalist, I suppose, than the quasi-liberal parents" (MacCabe and Kureishi 2003, p. 44). ${ }^{4}$

The changes in the dramatis personae and the relocation of My Son the Fanatic facilitate the film's shrewder approach not only to the nature of Islamic fundamentalism in a British Pakistani community, but also to wider issues defining and determining what it might mean to live an authentic Muslim life in a predominantly non-Muslim social and cultural environment. Pursuing these suggestions, this essay proceeds in two sections. First, "Farid Aziz and Deobandi Dawa" identifies the picture's portrayal of Farid's transformation into a fervent zealot with the South Asian Deobandi movement and its missionary offshoot the Tablighi Jama'at ("Preaching Party"). ${ }^{5}$ Next, "Parvez Aziz and the Sufi Ethos of Ihsān" analyzes the way in which subtler changes in the character of Parvez increasingly reflect the Sufi ethos of cultivating the good and beautiful, or ihssann, as his love for Sandra slowly blossoms. Drawing these analyses together, the conclusion argues that My Son the Fanatic stages ways of being Muslim which lie between equally unacceptable poles: the moral certainties of Farid's violent extremism and the amoral sinkhole represented by Schitz's more insinuous, but no less vicious materialist consumerism. Farid and Parvez both invoke the Qur'an, ultimate arbiter of value, meaning and truth in Islam, but their paths diverge widely. Most obviously, the film explores the revivalist maslak, or 'path', of the maulvi's Deobandi dawa, which literally means 'invitation', though such missionary enthusiasm may lead all too easily to the fundamentalist militancy of Farid and his cohort. On the other hand, the way in which My Son the Fanatic dramatizes the love between Parvez and Sandra in terms of tropes and themes transposed from the Sufi imaginary suggests conditions of possibility for living a Muslim life of sacralised secularity in diaspora in the postcolonial United Kingdom. ${ }^{6}$

\section{Farid Aziz and Deobandi Dawa}

As Melanie J. Wright has observed of Farid's metamorphosis from aspiring bourgeois scion to youthful Islamic enthusiast in My Son the Fanatic, "[ $t$ ]he incremental adoption of religious rituals stresses the constructedness of his identity: symbols, ideas and behaviours are adopted and adapted in order to articulate a social self at once conservative and contemporary" (Wright 2007a, p. 31). But Wright delves no further into the specific nature

4 Although Kureishi published an essay titled "Bradford" in 1986, the interview with MacCabe reveals that personal experience of the place does not inform either the essay or My Son the Fanatic:

I suppose I used to think that you had to write about what you knew. I set this film in Bradford, but to be honest, I've never been to Bradford, really. I've been there for a few weeks and written something about it, but I didn't know it very well. Then I thought, well, I don't really care, it's not really Bradford, it's in my mind. They never say it's Bradford [in My Son the Fanatic]. (MacCabe and Kureishi 2003, p. 44)

Kureishi also elaborates upon his preference for a reimagined Bradford over London as the setting for My Son the Fanatic:

[I]n London, in the Asian community, it's not so tight. You don't get the same concentration. In Bradford and Halifax, the hills are around, it's reasonably enclosed. It's tight. They argue among themselves. What people think and feel and do and say, it really matters and reverberates. So if a taxi driver has an affair with a prostitute, it's a big thing in the community. In London, it didn't seem to have the same kind of force. (MacCabe and Kureishi 2003, p. 44)

For a detailed account of the Muslim community in Bradford, see Philip Lewis [1994] (Lewis [1994] 2002).

5 Philip Lewis and Brandon D. Ingram separately translate the Tablighi Jama'at as the "Preaching Party" (Lewis 2004, p. 174; Ingram 2018, p. 139).

6 Different scholars intend different things by the terms "transposition" and "imaginary." On "transposition", phenomenologist of religion, Gerhard Van der Leeuw, provides this useful analysis:

'Transposition' is the variation of the significance of any phenomenon ... in the dynamic of religions, while its form remains quite unaltered.... 'Transpositions' ... appear at all times, but chiefly during reformations and missions.... Frequently, also, the actual character of a phenomenon is utterly lost in transposition .... [b]ut just as often ... the essence of the phenomenon ... is retained even when its interpretation has been modified. (Van der Leeuw [1933] 1938, pp. 610-11)

Philosopher Charles Taylor offers a helpful explanation of "imaginary":

[T] he way ordinary people 'imagine' their social surroundings ... is often not expressed in theoretical terms; it is carried in images, stories, and legends ... [This] social imaginary is that common understanding that makes possible common practices and a widely shared sense of legitimacy ... This understanding is both factual and 'normative'; that is, we have a sense of how things usually go, but this is interwoven with an idea of how they ought to go, of what missteps would invalidate the practice. (Taylor 2002, p. 106)

By no means exhaustive or exclusive, these understandings serve present purposes. 
of these "symbols, ideas and behaviours". In more precise historical terms, the Islamic elements constituting Farid's transformation resonate with the teachings of the Deobandis, a South Asian Sunni revivalist movement, and the proselytizing work, or dawa, of the associated Tablighi Jama'at. Founded in India in 1866 "in a milieu of waning Mughal power and rising British rule" in South Asia, the movement is named for the town of Deoband, Uttar Pradesh, where its leaders opened a seminary, the Dar al-'Ulum ("House of Higher Knowledge"), in 1867 (Sidat 2019, p. 2). ${ }^{7}$ Reforming Islamic education, the seminary's curriculum stressed "the revealed sciences of Qur'an and Hadith (reports of Muhammad's sunna, that is, his words, deeds and lifestyle), and the production of legal verdicts (Islamic jurisprudence, or figh), focused upon the moral reform of the individual" (Birt and Lewis 2011, p. 100). ${ }^{8}$ Over the following decades, the Deobandi maslak came to dominate Islamic education across the sub-continent. ${ }^{9}$

"Originally quiescent politically", John L. Esposito writes, the Dar al-'Ulum came to perceive British rule as inimical to the health of all things Islamic (Esposito 2003, p. 66). ${ }^{10}$ By the 1940s, Deobandi leaders were divided over the partition of the British Crown Raj along sectarian lines. The Indian Independence Act (1947) prompted a number of them to migrate from the newly created Union-later Republic — of India to join colleagues teaching at schools already established in the new Dominion-later Islamic Republic-of Pakistan (Zaman 1999, p. 310). ${ }^{11}$ In the following decades, the Deobandi maslak flourished in a plurality of Pakistan's madrasas. At the same time, Deobandi graduates established seminaries in South Asian diaspora communities around the world (Sidat 2018, p. 2). ${ }^{12}$ The first Deobandi schools in the postcolonial United Kingdom opened in the northern English towns of Bury, Lancashire, and Dewsbury, West Yorkshire, in 1975 and 1981

7 Historians generally recognize Islamic scholars Muhammad Qasim Nanaotawi (1832-1879) and Rashid Ahmad Gangohi (1829-1905) as the principal figures in this movement. Jonathan Birt and Philip Lewis describe the Deobandis as "the most important exemplars" of a spirit of "Islamic reform" that was "oppositional in character, defining itself against the popular custom of the Sufi shrines, other ulama, and non-Muslims, Hindu, and British" (Birt and Lewis 2011, p. 91, 92). This oppositional distancing, however, did not always take a passive form. Fuad S. Naeem notes, for example, "the participation of certain Deobandì 'ulamā in religious debates against missionary Christians and Arya Samaj Hindu revivalists, who aimed to convert Muslims back to Hinduism" (Naeem 2004, p. 93).

8 Haroon Sidat notes that the Deobandi "curriculum deliberately excluded English and western subjects" (Sidat 2019, p. 2). As Muhammad Qasim Zaman has remarked, however, the Deobandis readily adopted the administrative, bureaucratic and institutional conventions of British education, including "a set curriculum, separate classes for students of different levels, an academic year, annual examinations, and networks of affiliated madrasas" (Zaman 1999, p. 304). The Deobandis followed the Maturidi school of Sunni Islamic theology and the Hanifi school of Sunni Islamic law. Students focused almost entirely upon "intellectual work and its concomitant status", Barbara D. Metcalf writes, to the exclusion of "training in crafts and trades", which would have enabled graduates to "support themselves in villages and small towns", and of "surveying and cartography", which would have prepared graduates for jobs in the "public works department of the government" (Metcalf 1978, p. 119). "Only two kinds of vocational training had any place at the school", Metcalf writes: "calligraphy and țibb or yūnānī medicine" (Metcalf 1978, p. 119). Students considered these skills "suitable activities for the ulama" because they "related to the religious activities of copying manuscripts and healing their followers" (Metcalf 1978, p. 119). For a thorough account of the founding principles and early decades of the Dar al-'Ulum, see Metcalf (1978).

9 Brandon D. Ingram attributes the success of the Deobandi maslak in large part to "the career and writings of Qari Muhammad Tayyib (1867-1983), who presided over the Dar al-'Ulum Deoband as chancellor (muhtamim) from 1928 to 1980" (Ingram 2018, p. 139). "In the work of Tayyib", Ingram argues, "the concept of the maslak ("path" or "way") becomes a central category for theorizing the coherence of Deobandi tradition" (Ingram 2018, p. 139).

10 Dietrich Reetz attributes this shift in attitude to the Deobandi seminary's "new head teacher, Mahmud al-Hasan (1851-1921), and scholars such as Husain Ahmad Madani (1879-1957) and 'Ubaidullah Sindhi (1872-1944)" (Reetz 2007, p. 139).

11 The Deobandi maslak continued to expand across both territories. Two decades after partition, there were 8934 Deobandi madrasas in India and Pakistan (Esposito 2003, p. 66). According to Zaman, "in early 1994, there were estimated to be more than 2500 [madrasas] in the Punjab alone, the most populous of Pakistan's four provinces" (Zaman 1999, p. 310). For a succinct account of the genesis, evolution and impact of Deobandi Islam in the Pakistani province of Punjab, see Kamran (2016).

12 From the 1920s to the 1980s, Ingram has noted, "Deobandi madrasas were founded in countries as far-flung as the United Kingdom, South Africa, Trinidad and Tobago, and the United States" (Ingram 2018, p. 139). 
respectively (Lewis 2004, p. 171; Birt and Lewis 2011, p. 94). ${ }^{13}$ Significantly, however, more austere Salafi or Wahhabi ideas imported from Saudi Arabia and elsewhere gained increasing influence over the Deobandi curriculum both in Pakistan and in diaspora seminaries. ${ }^{14}$ In recent decades, Jawad Syed remarks, "Deobandis are closer to Salafis or Wahhabis in their inclination to takfiri [anathematizing], sectarian and jihadist militancy" (Syed 2016, p. 1).

At the same time, the Tablighi Jama'at, founded in the British Crown Raj in 1926, helped to propagate the Deobandi maslak. ${ }^{15}$ If the Deobandis were "educationists", writes Farish A. Noor, "the Tablighis were mainly lay missionaries" bent on saving Indian Muslims from the proselytizing campaigns "of both Christian missionaries from the West and Hindu revivalists in India" (Noor 2012, pp. 27-8). Tablighis focused their preaching on prayer, or salat, the six principles of faith, or iman, and the Faza'il-e-A'maal (Virtuous Deeds), an Urdu anthology of spiritually edifying stories drawn from the hadith. ${ }^{16}$ Loosely attached to Deobandi schools and often traveling in small groups, these missionaries encouraged "'lay" Muslims, high and low ranking, learned and illiterate, to share the obligation of enjoining others to faithful practice" (Metcalf 2002, p. 8). As Arsalan Khan puts it, "Tablighis describe dawat as a disciplinary practice that produces the interior state of faith and therefore lays the ground for all other Islamic practice" (Khan 2016, p. 100). ${ }^{17}$ Pursuing this strategy, the Tablighi Jama'at established a network of itinerant preachers in the north of the British Crown Raj, especially around Delhi. After the partition of the sub-continent, Tablighis broadcast their version of the Deobandi maslak across the newly formed dominions of India and Pakistan. By the 1970s, they had carried Deobandi teachings beyond South Asia to historically Muslim homelands in the Arabian peninsula, North Africa and Southeast Asia,

13 As Pnina Werbner has remarked, among "major groups" the Deobandis and the cognate Tablighi Jama'at came to dominate "the wide variety of different religious streams, denominations and movements evident in South Asia [and] transposed into Britain almost wholesale, along with the migration of Muslims from the subcontinent" (Werbner 2004, p. 904). "By the early twentieth century", Bowen likewise notes, "three religious pathways-Deobandi, Ahl al-Hadith, and Barelvi—had established themselves in north-central India as distinctive, alternative ways of living a life as a Sunni Muslim" (Bowen 2016, pp. 30-31). In the decades after World War II, Bowen continues, the competitive character of this "Islamic triangle', (Deobandi/Barelvi/Ahl al-Hadith)", most notably "the opposition Deobandi/Barelvi, has been foundational for the development of Islamic institutions in [Great] Britain" (Bowen 2016, p. 31). In particular, the Deobandi maslak enjoys widespread influence in the former colonial power. Of the 22 Islamic seminaries established to serve south-eastern and northern English centres of South Asian migration before the end of the 20th century, fourteen adhere to the Deobandi curriculum (Lewis 2004, pp. 171-2; Birt and Lewis 2011, pp. 93-5). The syllabus includes Arabic literature and language, the life of Muhammad and his companions, the history of early Islam, and "the canonical Hadith collections", which form "the apex of study" (Birt and Lewis 2011, p. 100). Bowen notes that "[t]he Bury seminary is the largest in the UK and, either directly or through its affiliated schools, dominates the world of British Deobandi seminary training" (Bowen 2016, p. 36). For details on the varieties of Muslim identity in the postcolonial United Kingdom, see Arun-Qayyum (2016).

14 Some clarification of terms may be helpful here. Named for Muhammad Ibn Abd al-Wahhab (1703-92), Wahhabi Islam originates in 18th-century Saudi Arabia as a militant, iconoclastic, scripturally literalist and puritanical sect intent on returning Islamic life to the days of Muhammad and the early Muslim community. In the 19th century, the Salafi movement revived the Wahhabi agenda on an international scale in response to western European colonial imperialism. Deriving from the Arabic salaf, a collective usage meaning 'pious predecessors', "Salafi" refers to the original companions of Muhammad, or more widely, to the first four generations of Muhammad's followers, most notably the founders of the Hanafi, Maliki, Shafi'i and Hanbali schools of Sunni Muslim jurisprudence (Abbas 2011, p. 23). Unlike "Wahhabi", the moniker "Salafi" encompasses a range of revivalist and fundamentalist Islamic groups, whatever ritual, ethical and doctrinal differences distinguish them one from another. More austere Salafis may speak of themselves as Wahhabis, but the terms are not interchangeable. Although the conservative jurisprudence and theology of Ahmad ibn Hanbal (780-855) and Taqī ad-Dīn Ahmad ibn Taymiyyah (1263-1328) influences both movements, in Hashmi's words, "all Wahhabis are Salafis but not all Salafis are Wahhabis" (Hashmi 2016, p. 136).

15 Ingram notes that Qari Muhammad Tayyib "became a staunch advocate" of the Tablighi Jama'at, but historians usually attribute the founding of the movement to the Deobandi scholar, Muhammad Ilyas al-Kandhlawi (1885-1944) (Ingram 2018, p. 139). On this genealogy, see Haq (1972). For a general history of the Tablighi Jama'at, see Sikand (2002). Reetz considers the Tablighi Jama'at "to be a main propagator of Deobandi reformist thought" (Reetz 2007, p. 144). As Birt and Lewis have argued, whatever their organizational differences, "the Tablighi Jamaat has been essential in supporting the rapid institutionalization of the Deobandi movement" (Birt and Lewis 2011, p. 109).

16 Ilyas's nephew, Tabligui Jama'at scholar Muhammad Zakariya Kandhalawi (1898-1982), composed the Faza'il-e-A'maal. For a succinct analysis of the "foundational literature of the Tablighi Jama'at and its role in defining the movement", see Noor (2012, pp. 63-87).

17 Historians generally recognize Islamic scholars Muhammad Qasim Nanaotawi (1832-1879) and Rashid Ahmad Gangohi (1829-1905) as the principal figures in this movement. Jonathan Birt and Philip Lewis describe the Deobandis as "the most important exemplars" of a spirit of "Islamic reform" that was "oppositional in character, defining itself against the popular custom of the Sufi shrines, other ulama, and non-Muslims, Hindu, and British" (Birt and Lewis 2011, p. 91, 92). This oppositional distancing, however, did not always take a passive form. Fuad S. Naeem notes, for example, "the participation of certain Deobandì 'ulamā in religious debates against missionary Christians and Arya Samaj Hindu revivalists, who aimed to convert Muslims back to Hinduism" (Naeem 2004, p. 93). 
and by the 1990s, to migrant Muslim minorities in the Caribbean, Europe, North America and South Africa (Haq 1972, pp. 176-78). ${ }^{18}$ After occasional appearances in the 1950s, Tablighis began to enjoy a permanent presence in the United Kingdom "from the late 1960s onwards" (Noor 2012, p. 210 n. 83). ${ }^{19}$ Yet here again, by the 1990s the missionaries often adopted the more activist attitude to dawa that had come to characterize Deobandi teaching more widely. Most notably, as Sam Westrop remarks, Saudi Arabian Wahhabi support sometimes results in a "Tablighi rhetoric [that] seems to be as exclusivist and illiberal as the Deobandi Bury network" (Westrop 2016, p. 464). ${ }^{20}$

It is within the transnational context of this "Deobandi teaching and Tablighi mobilization" that we may locate the northern English figures of Farid Aziz and his revivalist Muslim cohort in My Son the Fanatic (Reetz 2007, p. 157). Expanding on Kureishi's short story, the film opens with a depiction of upper middle-class Caucasian British comfort: a country house of classical design looks out over a lake; cows graze nearby in a lush meadow; and a Union Jack flutters high on a pole amidst picturesque gardens. An interior sequence follows, and we meet the Aziz family celebrating Farid's engagement over afternoon tea with his fiancée, Madeline (Sarah-Jane Potts), her mother (Judi Jones) and later her father, police Chief Inspector Fingerhut (Geoffrey Bateman). Dressed in a suit and tie, Farid looks every bit the upwardly mobile young professional his father intends him to become. His perspective coloured by the moment, however, Parvez is totally oblivious to the racist disdain which the Fingerhuts clearly feel towards their guests. ${ }^{21}$ Farid's vision is clearer. He soon breaks up with Madeline, but without telling his father. It is Madeline who explains when Parvez visits her at work in a bank: "He wanted someone he had more in common with" (Prasad 1997, 00:19:26). Non-plussed, Parvez proposes a meeting with the Chief Inspector. "You don't know anythin', do ya?" Madeline replies sympathetically, repeating her ex-fiancé's brutal pun on the consumption of pork as forbidden, or haram, in Islam: "Farid told my father he was the only pig he ever wanted to eat" (Prasad 1997, 00:19:38-45). As Farid later elaborates over dinner in Fizzy's restaurant: "The girl is okay, but Fingerhut. Couldn't you see how much he hated his daughter bein' with me? And how repellant he found you. I never want to see those people again" (Prasad 1997, p. 12-20).

18 Marc Gaborieau argues that Ilyas intended to develop the Talblighi Jama'at not only into a sub-continental movement, but also into an international phenomenon (Gaborieau 2000). Scholars generally credit the dispersion of the Tablighi Jama'at beyond South Asia to the work of Ilyas's son, Maulana Muhammad Yusuf (1917-65), "under whose leadership the T[ablighi] J[ama'at] managed to expand to over 30 countries in various continents" (Sikand 1998, p. 174).

19 John King notes that by the mid-1990s, the Tablighi Jama' at enjoyed "a national structure" in the United Kingdom, "whose centre is at the Markazi Mosque and its associated madrasa (school) at Dewsbury, sometimes known as the Dar ul-Uloum, whose official title is Jamiat Talimul Islam" (King 1997, p. 130). From this centre, missionaries preach the Deobandi maslak, filtered through the Tablighi Jam'at's focus on "fazail [virtues], namaz [salat or prayer] and iman" (Sikand 1998, p. 179). Indeed, the Deobandi school in Dewsbury operates not only as a national base for the missionary movement, but also as "the center for European activities" (Bowen 2016, p. 36).

20 In this respect, for example, Arshi Saleem Hashmi notes that Abdul Aziz ibn Abdullah ibn Baz (1910-99), "the most influential Wahhabi cleric of the late twentieth century, recognized the Tablighis' good work and encouraged his Wahhabi brethren to go on missions with them so that they could direct and give advice to them" (Hashmi 2016, p. 140). Citing Alex Alexiev, Westrop links Saudi Arabian Wahhabi interests with the Dewsbury mosque quite explicitly. "In 1978", he writes, "the construction of the T[ablighi] J[ama'at] mosque in Dewsbury was subsidized by the World Muslim League, a Saudi organization that funds Salafist causes" (Westrop 2016, p. 464; citing Alexiev 2005).

21 Here and elsewhere in this essay, "caste" might be a more fitting category than "race" for the embedded sense of entitlement felt by the senior Fingerhuts and other Caucasians with respect to the Aziz family and other Pakistani migrants in My Son the Fanatic. Isabel Wilkerson has written at length of this distinction (Wilkerson 2020b). In "America's 'Untouchables': The Silent Power of the Caste System", she captures the core of her argument:

Caste and race are neither synonymous nor mutually exclusive. They can and do coexist in the same culture, and serve to reinforce each other. Caste is the bones, race the skin. Race is what we can see, the physical traits that have been given arbitrary meaning and become shorthand for who a person is. Caste is the powerful infrastructure that holds each group in its place. Caste is fixed and rigid. Race is fluid and superficial, subject to periodic redefinition to meet the needs of the dominant [Caucasian] caste .... (Wilkerson "America's 'Untouchables'(Wilkerson 2020a))

Wilkerson is talking about issues of prejudice and discrimination in today's United States of America.

Her line of reasoning might well be adapted to the analysis of analogous matters in the postcolonial United Kingdom. Establishing such a case, however, lies beyond the scope of this essay. 
We soon learn that it is Farid's indignation at such British racial prejudice that prompts his sudden interest in a conservative form of Islam. ${ }^{22}$ In turn, this freshly acquired piety propels a rejection of the kind of life Parvez has planned for his son. No, Farid will not wed Madeline, but he assures his father that he is intending to marry. In this respect, he has "asked trusted people for a suitable girl" (Prasad 1997, 00:24:12). Farid's use of the words "trusted" and "suitable" here chimes with exclusivist elements of Deobandi teaching. In the words of Bulbul Siddiqi, "most young Tablighi Jamaat followers marry someone who also has the Tablighi Jamaat back-ground" (Siddiqi 2018, p. 102). In a later exchange with Parvez, Farid elaborates upon his position:

Farid: You might not have noticed. Madeline is so different. ... Can you put keema [minced meat] with strawberries? In the end, our cultures-they cannot be mixed.

Parvez: Everything is mingling already, this thing and the other.

Farid: Some of us are wanting something more besides muddle ... Belief, purity, belonging to the past. I won't bring up my children in this country. (Prasad 1997, pp. 28-52)

In terms at once ethnic and theological, Farid's desire for the perceived certainties of "[b]elief, purity, belonging to the past" clearly reflects conservative Deobandi teaching. Farid's rejection of Madeline does not rest wholly upon her ethnic difference; of greater significance is the fact that she is not a practicing Muslim. For adherents of the Tablighi Jama'at "looking for a bride", Siddiqi remarks, "finding a deendar [religiously observant] woman is the most important issue" (Siddiqi 2018, p. 103).

Subsequent sequences in My Son the Fanatic testify to the influence of Deobandi ideas upon Farid's religious transformation. As in "My Son the Fanatic", he rids himself of the accoutrements of adolescence. But cinematics enlarge our appreciation of the complexity of Farid's motives. In a telling scene, for example, a hubbub outside the house draws Parvez to the living-room window. The camera frames three figures in the street: Farid, Madeline, and a Caucasian youth packing items into a car. Brandishing an electric guitar in one hand, Farid dismisses his distraught fiancée with the other: "Just go! Now! I want you to go right now!" (Prasad 1997, pp. 37-43). A concerned Parvez rushes from the house as Madeline runs away and Farid completes the sale of the guitar to the young Caucasian. Visually, these frames locate Farid's rejection of Madeline within the deeper rejection of western popular culture metonymized in the figure of the traded guitar. That said, the sale of the guitar prompts an ambiguous exchange between father and son:

Parvez: You used to love making a terrible noise with these instruments.

Farid: You always said there were more important things than 'Stairway to Heaven'. (Prasad 1997, pp. 13-16)

Subtle ironies pervade Farid's reply to his puzzled father's affectionate teasing. For the ostensibly acculturated Parvez, "more important things than 'Stairway to Heaven" will have meant Farid's future success as an accountant. Farid, however, intends his newly found sense of spiritual commitment. In this respect, the disposal of the guitar as a fetishized icon of the culture he now so vehemently disdains reflects the Deobandi teachings of "Pakistani Muslim religious leaders in Britain", for whom "popular culture-music,

22 As an anonymous reviewer of this essay suggests, in this and related matters My Son the Fanatic invites closer sociological analysis. Though not the primary focus here, such concerns in the film are addressed in terms of the contrasting responses of first- and second-generation Muslim migrants to life in the postcolonial United Kingdom by Trine Winter Mortensen (2005), and more broadly in terms of the multicultural politics of race and ethnicity among Muslims in Great Britain by Tariq Modood (2005, passim). 
dance and expressions of sensuality—is rejected as sinful" (Werbner 2004, p. 898). ${ }^{23}$ Conversely, by reiterating Parvez's derogation of Led Zeppelin's "Stairway to Heaven" (1971), Farid sounds as if he is discrediting spiritual aspiration, even as his words foreground a rock-and-roll classic that, according to Dave Lewis, dramatizes "a search for spiritual perfection" (Lewis 1991, p. 52). ${ }^{24}$

The sequence featuring the sale of the electric guitar closes with another ironic twist: Farid's moralistic strictures soften to filial affection, as he carries his bare-footed father back across the street to the house lest Parvez "catch pneumonia" (Prasad 1997, 00:13:23). ${ }^{25}$ As My Son the Fanatic proceeds, however, so visual and aural elements awaken us to the hardening of Farid's puritanical piety. Stripped of the trappings of adolescence, his room now features a prayer rug and a poster giving instructions for wudu, the formal ablutions that precede Muslim devotions (Prasad 1997, 00:25:55). ${ }^{26}$ Later in My Son the Fanatic, we witness Farid learning how to pray. Sequestered in his bedroom, he listens to a tape in Arabic (Prasad 1997, 00:25:56-26-12). His use of modern technology typifies "the ironic characteristic of fundamentalisms ... that they often combine a commitment to a selectively imagined past with an easy facility with modern technology" (Bruce 2008, p. 14). ${ }^{27}$ The issue of language is important here, too. Muslims believe that the archangel Jibril, or Gabriel, conveyed the words of the Qur'an directly from God to Muhammad in Arabic. "For Muslims", Tahir Abbas writes, "the divine word assumes a specific Arabic form, and this form is as essential as the meaning that the words communicate" (Abbas 2011, p. 6). Each of the five prescribed daily prayers of Islam begins with the first chapter, or sura, of the Qur'an, known as Al Fatihah, that is, "The Opening." As Metcalf notes, Deobandi leaders have always been "devoted to the correct performance of the canonical prayer, the most important and frequent of the Islamic religious duties" (Metcalf 1978, p. 149). The Deobandi focus upon salat thus renders knowledge of Arabic still more crucial.

It is important to recognize that My Son the Fanatic does not portray Farid as an isolated loner; he belongs to a group of equally pious peers. Forming in small bands of fellow believers is a basic strategy of the Tablighi Jama'at, for whom, in Khan's words, "dawat is a 'collective practice' (ijtimai amal) rather than just an 'individual practice' (infaraadi amal)" (Khan 2016, p. 100). Immediately after the scene depicting Farid attending to the taped instructions on salat, we join Parvez in his taxi as he watches his son and his cohort approaching a local mosque (Prasad 1997, 00:26:16). Now Farid combines western dress with a traditional kameez and a taqiya cap, reflecting his metamorphosis from aspiring bourgeois scion into budding Muslim revivalist. Inside the mosque, the camera catches a resolute look on Farid's face, as he leads his colleagues into the prayer hall. Unseen, Parvez follows the group. There are heated exchanges between the youths and other worshippers. An older man confides to Parvez: "These boys are not welcome. They're always arguing with elders. They think everyone but them is corrupt and foolish" (Prasad 1997, 00:27:03-08). At the same time, however, the elder concedes a certain admiration

23 Compare here sociologist Deena Weinstein's account of western popular culture's "guitar gods", who "make a fetish of their instruments" (Weinstein 2013, p. 150). Conversely, Diana Harris writes of a British Deobandi imam who, not untypically, "does not accept the use of any musical instruments and listens to no music at home" (Harris 2002, p. 56). For the imam, Harris continues, "music is always linked with other matters which are haram [forbidden], such as fornication, alcohol and drugs" (Harris 2002, p. 56). Just as importantly, devout Muslims consider popular music "incompatible with being a hafis, a reciter of the Qur'an, because it [the Qur'an] has a sound system of its own which doesn't mix with other types of music" (Harris 2002, p. 56).

24 In a similar vein, Susan Fast's detailed analysis of "Stairway to Heaven" reveals "how the musical discourse taps into mythical and ritualistic constructs that are entrenched in Western culture" (Fast 2001, p. 10). "Stairway to Heaven", she concludes, encodes "the weightiness and uncertainty of spiritual journeys" and epitomizes the "mythic, epic, and ritualistic aspects of Led Zeppelin's music" (Fast 2001, p. 63).

25 It is worth noting, too, that throughout these scenes, the more westernized Parvez wears a traditional shalwar kameez, while Farid is dressed in a sweater and jeans.

26 Prayer, or salat, constitutes the second of the Arkan al-Islam, or Five Pillars of Islam, specified in the Qur'an as active obligations incumbent upon all Muslims. Muslims pray five times a day: at dawn, at midday, in the afternoon, at sunset and at night.

27 Deobandis seem always to have taken advantage of the latest technology. Metcalf notes that the movement's founders in nineteenth-century India "gained support by utilizing all types of new technologies, from printing presses to the post office to railroads" (Metcalf 2002, p. 4). More recently, Lewis writes of a graduate from Bury's Deobandi seminary who "developed a flourishing audio cassette ministry" (Lewis 2004, p. 177). 
for the youths: "They're not afraid of the truth. They stand for something. We never did that." (Prasad 1997, 00:27:10-18). Although this fictionalized 'Bradford' congregation's senior members likely would themselves have adhered to the Deobandi maslak, the elder's remarks testify to what Abbas describes as "acute inter-generational differences" between first- and second-generation South Asian Muslims in the postcolonial United Kingdom. ${ }^{28}$ In the 1960s and 1970s, "quietistic and non-controversial" Tablighi Jama'at delegates usually proselytized in mosques only when invited (Sikand 1998, p. 179). By the 1990s, however, the movement's "efforts to 're-islamize' large numbers of Muslims" had begun to provide "a fertile ground for the activities of Islamic political parties and radical or militant groupings" (Reetz 2004, p. 289).

Another early sequence soon shows Farid and colleagues in studious pursuit of the "truth" to which the elder alludes. Each attired in a mix of western and South Asian clothing, they are seated cross-legged in an informal study circle, or halaqa, on the floor of Farid's bedroom (Prasad 1997, 00:38:00). In their midst, we see a copy of the Qur'an. The Tablighi Jama'at's thinking on the study of scripture at once mirrors and complements the movement's views on dawa. Members are expected to take part regularly in a learning session, or $t a^{\prime} l e e m$, to help to develop and maintain their evangelizing acumen, and like evangelizing, the study of the Qur'an is a group affair (Siddiqi 2018, p. 3). As Siddiqi notes: "Senior leaders of the Tablighi Jamaat always put stress on the importance of group work, for example, dawah, ta'leem, ijtema [gathering], gasht [visitation]. Every task is done in groups" (Siddiqi 2018, p. 155). ${ }^{29}$ Cinematic details further testify to the vigilance with which Farid and his peers approach their studies. For example, the Qur'an rests open upon a folding $x$-shaped stand, or rehal, in careful observation of an enduring Islamic injunction against placing the sacred scripture directly on the floor. ${ }^{30}$ Likewise, the camera captures Farid nodding in thoughtful agreement as a fellow discussant avows the boundless beneficence of Allah and the responsibilities of Muslims as dutiful stewards of the divine dispensation: "Allah's given us the earth and all things natural within it. It's all gifts. We have to look after every single thing" (Prasad 1997, 00:38:02-38:25). A contemporary adherent to the Tablighi Jama'at expresses this fundamental Deobandi doctrine of grace: "The only appropriate analysis of Tablighi Jama'at puts God at the center and sees that all else rests on His grace [baraka]" (Metcalf 1996, p. 118). ${ }^{31}$

Farid's dinner with Parvez in Fizzy's restaurant provides the context for the young enthusiast's most fateful initiative and reveals most explicitly the radically conservative nature of the kind of Islam that informs it. Asserting that he has been "thinking seriously", Farid launches into a moral critique of contemporary British society: "They say integrate, but they live in pornography and filth and tell us how backward we are ... A society soaked in sex" (Prasad 1997, 00:41:05-24). Though stark in tone, Farid's words express a not uncommon conservative Muslim view of western ways. Among other aspects of British lifestyles, John R. Bowen writes, "unregulated sexuality makes secularism unacceptable", especially to the more conservative elements of "British Islam" (Bowen 2016, p. 226). ${ }^{32}$ More constructively, however, Farid informs Parvez that his group has invited "a wise

28 As Bowen observes: “Coordination among Deobandi schools and mosques in the Bradford area comes from their ties to the two oldest schools at Bury (fifty miles west of Bradford) and at Dewsbury (ten miles south)" (Bowen 2016, p. 36).

29 Siddiqi explains that for the Tablighi Jama'at ta'leem "refers to a session where members read from the Qur'an and hadiths in a group" in order "to acquire knowledge on hadith and to learn to read properly the verses of the Qur'an that people need to recite in the daily prayer" (Siddiqi 2018, p. 3).

30 Since Muslims believe that the Qur'an is a flawless copy of the literal word of Allah, strict conditions have long applied to the handling of the physical text. Introducing the Tafsir al-Qurtubi: Classical Commentary of the Holy Qur'an, for example, the celebrated Andalusian scholar and jurist Abu 'Abdullah al-Qurtubi (1214-73) advises: "Part of respect for it [Qur'an] is that when you recite, you put it in your lap or on top of something in front of you and do not put it on the ground" (Al-Qurtubi 2003, p. 30).

31 Elsewhere, Metcalf explains the practical implications of the Deobandi doctrine of grace: "Their followers judged the Deobandi maslak ... to be one that truly had as its foundation and goal obedience to the religious Law and, on that account, to be a program for their daily lives and a preparation for the receipt of God's grace-a solution to their problems of both world and of soul" (Metcalf 1982, p. 140).

32 Compare Westrop, who writes that "Deobandi Islam [strives] to gain influence over British Muslims by asserting its role as a voice of British Islam" and that "a considerable number of Deobandi ulema continue to warn Muslims not to mix with the kufr (a derogatory term for non-Muslims) and to reject the iniquities of Western mores" (Westrop 2016, p. 460). 
Maulvi from Lahore ... a good man ... to offer us a little instruction" (Prasad 1997, 00:41:31-36). Here again, the young enthusiasts are taking advantage of the Tablighi Jama'at's transnational missionary strategy "to provide an intensive religious training for individuals who have never attended traditional places of Islamic learning" (Takim 2016, p. 498). At the same time, it is important to note that Farid follows traditional Islamic teaching in respecting his father's parental status, as he seeks "permission" for the Punjabi cleric to "stay a few days" (Prasad 1997, 00:41:41-42). ${ }^{33}$ As scriptural literalists, both Deobandi and Tablighi Jama'at adherents recognize "filial piety" as "a major theme of the Qur'an", to use Fazlur Rahman's phrase (Rahman [1980] 2009, p. 42).

Parvez acquiesces to Farid's request, but asks his son if he is keeping up with his studies in accountancy. The question prompts Farid to spell out more clearly his reasons for abandoning such a career (Prasad 1997, 00:43:06). "Accountancy is just capitalism and taking advantage", he argues; "[i]t requires you "to go to the pub and meet women", many of whom, he adds, "lack belief and therefore reason" (Prasad 1997, 00:43:06-19). Farid's remarks imply Islam's universal proscription against the consumption of alcohol. He is clearly more concerned, however, to stress longstanding Deobandi doctrine on the segregation of the sexes. The Tablighi Jama'at, writes Khan, view women "as a 'temptation' or fitna, a word that also means a state of moral chaos of which women are widely understood to be the primary source" (Khan 2016, p. 102). "Gender segregation", Khan continues, "is therefore a basis for moral order" (Khan 2016, p. 102). By contrast, Farid asserts, "[t]here are suffering men in prison who require guidance": "I've never met men more sincere or thirsty for the spirit" (Prasad 1997, 00:42:55-43:04). Here, Farid very much echoes contemporary Deobandi preoccupations with the moral and spiritual wellbeing of incarcerated Muslims. "In the UK", Westrop writes, "the imposition of the Deobandi orthodoxy is most clearly seen within chaplaincy programmes" (Westrop 2016, pp. 453-54). More specifically, Bury's Deobandi seminary led the way in training Muslim chaplains for service in the United Kingdom's prisons (Westrop 2016, p. 468). ${ }^{34}$

The restaurant sequence builds to a climax as Farid invokes the Qur'an in a pietistic assault upon his father. "Papa", Farid pronounces, "the final message [the Qur'an] is a complete guidance" (Prasad 1997, 00:43:21). He implores Parvez "to seek Allah's forgiveness for [his] mistakes" (Prasad 1997, 00:43:22-28). Echoing "the isolationist, anti-Jewish and anti-Western rhetoric of senior Deobandi clerics" in the postcolonial United Kingdom, Farid berates his father for having "swallowed the white and Jewish propaganda that there is nothing to our lives but the empty accountancy of things, for nothing!" (Westrop 2016, p. 461; Prasad 1997, 00:43:22-38). ${ }^{35}$ Farid's racist and anti-Semitic attack leaves his father broken and confused. The sequence ends with a distraught Parvez stumbling intoxicated from the restaurant. In gestures alternately judgmental and generous, Farid rebukes Fizzy

33 By contrast, in the context of "marriage and social boundaries among British Pakistanis", Philip Wood notes that sometimes "[t]he loss of filial piety is ... seen as a typical result of exposure to Western society, where the intergenerational contract has broken down" (Wood 2011, p. 51).

34 Commenting on official statistics for 1997, the year My Son the Fanatic premiered, The Guardian's Alan Travis notes the escalating numbers of Muslim inmates in the United Kingdom's prisons:

The 1997 figures show the number of people imprisoned per 100,000 population was 176 for whites; 1249 for blacks; 86 Indian; 278 Pakistani; and 101 Bangladeshi. The rates suggest that while a disproportionate number of black people were behind bars compared with whites, the proportions for the Asian communities were not much different. (Travis 1999)

In the mid-1990s, authorities began to pay attention to the religious needs of incarcerated Muslims.

Lewis, for example, tells of a graduate from Bury's Deobandi seminary who was "one of the first imams appointed to prison chaplaincy in 1996" (Lewis 2004, p. 177). In 1999, Her Majesty's Prison Service appointed Maqsood Ahmed as the United Kingdom's first special advisor on Muslim issues. As Westrop reports, Ahmed "chose to solicit candidates for [prison] chaplaincy from [the Deobandi] Darul Uloom Bury" (Westrop 2016, p. 470).

35 Though unwarrantedly antisemitic, Farid's frustration with entrenched British bigotry is justified: witness not just the unease of the Fingerhuts with the Aziz family's presence in their home, but more disturbingly, the racist abuse poured upon Parvez at the Manningham Night Club by a stand-up comedian and his audience, which includes local police (Prasad 1997, 00:29:36-30:31). As Wright points out, this sequence helps to establish the "realist credentials" of My Son the Fanatic, since "Manningham Night Club" references "the Bradford riots of 1995 (in which a Manningham brothel was razed to the ground) and the appearance in the same year of racist 'comedian' Bernard Manning at a Greater Manchester Police dinner" (Wright, "Re-Viewing My Son the Fanatic", Wright 2007a, p. 36). 
for plying Parvez with alcohol, then drives his father home. ${ }^{36}$ That is to say, Farid's filial duty plays out as a finely nuanced weave of evangelical responsibilities intertwining his own spiritual welfare with Fizzy's and his father's. Farid will see Parvez safely home, yes, but he will also cast judgment upon Fizzy for enabling his father's intoxication, and most importantly, he will render his refusal to consent to his father's career counselling in terms of an ethical and scripturally based Deobandi critique of western economic, social and cultural mores. As Rahman has noted of conservative schools of scriptural interpretation, when "serious tensions [arise] between natural blood ties (including filial piety), on the one hand, and loyalty to truth, righteousness or the community on the other, unflagging concern for the latter is uncompromisingly demanded" (Rahman [1980] 2009, p. 42). ${ }^{37}$

Farid's preference for proselytizing among the spiritually deprived in men's prisons over accountancy and drinks with untrustworthy women in pubs propels him to proceed with the visit of the Punjabi religious scholar. Mistakenly assuming that his father's acquiescence to the visit means that Parvez is "beginning to see things from another point of view", Farid presses ahead with arrangements for the maulvi's arrival (Prasad 1997, 00:47:00). He and his colleagues spruce up Parvez's taxi and the Aziz home, even replacing secular pictures assumed offensive to the cleric with more agreeable Islamic images. Dragooning his father into using the taxi to pick up the maulvi from the airport, Farid reaffirms his missionary mantra: "The people are thirsty. Thirsty!" (Prasad 1997, 00:48:20). Like his fellows, Farid's dress now bespeaks a still fuller engagement with the revivalist cause, as a Punjabi shalwar replaces denim jeans, complimenting the kameez and taqiya we have already seen him wearing. Here again, Farid adheres more closely to Deobandi teaching. In Sikand's words, "Tablighi tended to see ... Western dress as somehow outside the bounds of Islamic modesty" (Sikand 1998, p. 180). ${ }^{38}$ At the airport, Farid and the maulvi lead the group from the terminal building to Parvez and the taxi. As we might expect, the cleric is also dressed in traditional Punjabi Muslim clothes. He wears a full beard, as well. ${ }^{39}$ Such scrupulous attention to appearance expresses the sect's literalist determination to recapitulate the physical look of Muhammad. ${ }^{40}$ In the taxi, an exchange between Farid and the maulvi testifies further to the increased influence of austere Salafi thinking upon the Deobandi maslak in the later 1990s. Farid couches a commentary on the post-industrial cityscape of the film's fictional 'Bradford' in terms of a conservative Islamic critique of colonial capitalism. An "extremely tall chimney", he notes, "perfectly symbolizes the overblown ego of the British industrialists in the 19th century" (Prasad 1997, 00:49:00-06). He recalls enthusiastically

36 Further complicating the push and pull of evangelical responsibilities with which Farid is wrestling, this sequence of My Son the Fanatic differs noticeably from "My Son the Fanatic." At Fizzy's prompting, Farid drives his intoxicated father home, whereas "the boy sat in the back of the taxi" in the short story, "as if he were a customer" (Kureishi 1997, p. 104).

37 Rahman reflects the views of the highly influential Deobandi scholar Ashraf 'Ali Thānawi (1863-1943), whose treatise "Balancing Parental Rights", according to Fareeha Khan, warns that "to expend too much effort in trying to please one's parents may not only be mentally and spiritually daunting, but also damaging to one's religious faith" (Khan 2009, p. 308).

38 "T[ablighi] J[ama'at] activists", Sikand writes, "generally wore ... traditional South Asian attire—baggy trousers or shalwars or lungis, a long, wide cloth wrapped around the waist, knee-length shirts or kurtas or katneez, or Arab-style gowns, along with either skull-caps or turbans" (Sikand 1998, p. 180). Similarly, Muhammad Moj reports that Deobandi students surveyed in Pakistan "thought that only shalwar kamiz ... was suitable Islamic dress" (Moj 2015, p. 187). "All of them condemned pants and jeans as un-Islamic", Moj continues, for such clothes "evince the shape of the body parts because they are tightly attached to the skin" (Moj 2015, p. 187). Indeed, for the Tablighi Jama'at worldwide, the shalwar khameez is "de rigueur" (Noor 2012, p. 148).

39 The style of facial hair is a matter of doctrine for Deobandis. As Sikand notes of Tablighi Jama'at men, "the moustache is generally shaved off and great stress is given to growing a beard, the ideal recommended length of which is at least 'one fist full'" (Sikand 1998, p. 189).

40 "It is a Sunnah [practice of Muhammad]", Siddiqi writes, "for a Tablighi Jamaat man to grow a beard and to maintain dress code" (Siddiqi 2018, p. 163). If the more doctrinaire Deobandi shaves his moustache, however, the maulvi retains his, perhaps indicating a more relaxed interpretation of this aspect of the tradition's teachings. 
that "the Ayatollah Khomeini wore a robe made here" (Prasad 1997, 00:49:14). ${ }^{41}$ As Parvez drives past sex-workers, his son remarks on the ubiquitous "immorality" of western society (Prasad 1997, 00:49:41). Apparently encouraging a public demonstration of Muslim moral outrage, the Punjabi cleric challenges Farid: "And yet you take no action?" (Prasad 1997, 00:49:43).

Subsequent sequences involving the maulvi further enlarge our understanding of the kind of Islamic values to which Farid and his cohort ostensibly adhere. A quick transition takes us from the interior of the taxi returning from the airport to a television cartoon featuring a burly white working-class male in undershirt, black trousers, and boots kicking his wife into a garbage can (Prasad 1997, 00:49:50). A reverse shot reveals the cleric laughing at the cartoon over a cup of tea. ${ }^{42}$ If his comedic taste is immature, at a deeper level it is seemingly misogynistic. Either way, the arrival of the Punjabi cleric precipitates the introduction of more strictly defined gender roles into the Aziz home. ${ }^{43}$ In the sequence depicting Farid and his peers studying the Qur'an, for instance, Minoo brings the young male students tea on a tray, but she pointedly maintains physical separation from them through a half-open door, her hair and neck now fully concealed beneath a tightly wound scarf, or dupatta, in accordance with conservative Islamic teaching (Prasad 1997, 00:37:46). ${ }^{44}$ Nor must we assume that Minoo is an unwilling participant in gender segregation; on the contrary, she seems not only to approve of Farid's new direction in life but also to have chosen to accompany him in it. ${ }^{45}$ If "the Tablighi Jama'at's narrow and restricted gender regime in fact reinforces women's subordination", as Siddiqi writes, it is nonetheless the case, as Metcalf has observed, that "women themselves often take independent initiative in participation" and see such decisions "as serving their own interests" (Siddiqi 2018, p. 114; Metcalf 1998, p. 110). In this respect, later scenes in My Son the Fanatic confirm Minoo's reversion to tradition as a deliberate decision. While Parvez, Farid and the maulvi eat at the dining-room table, for example, Minoo takes her meal alone in the kitchen behind a closed door, deliberately turning her back on Parvez when he asks her to join the men (Prasad 1997, 1:00:36-1:01:24). On another occasion, Minoo shuts out Parvez from the kitchen, where she and other women prepare food for the cleric and his acolytes, who are using other downstairs areas to organize their proselytizing work (Prasad 1997, 1:09:01).

Under the watchful eye of the visiting Punjabi maulvi, then, Farid and the other young reformers turn the Aziz home into a base of operations for a missionary campaign focused on what Aparna Bhar has called "the moral cleansing of the city" (Bhar 2014, p. 223). On his way to work in the taxi, Parvez witnesses them in action, as the cleric leads Farid and his cohort in a campaign to reform the red-light district of this fictional 'Bradford'. Handed proselytizing leaflets, sex workers accuse the Muslim youths of being "sodding do-gooders" (Prasad 1997, 1:01:45). Worse, in a later scene Bettina's colleague Margot

41 Farid seemingly assumes that the Pakistani Sunni scholar will share the Iranian Shia mullah's general disdain for all things western. Given Kureishi's admission that My Son the Fanatic is set in a fictionalized Bradford, this assumption is likely not misplaced. On 14 January 1989, Deobandi leaders of the Bradford Council of Mosques organized a public burning of Rushdie's The Satanic Verses, prefiguring the fatwa calling for the novelist's death issued by Khomeini exactly one month later (Westrop 2016, p. 456). Interestingly, Metcalf notes that Roy P. Mottahedeh's account of Shi'a Muslim education in The Mantle of the Prophet: Religion and Politics in Iran "resonates broadly" with the kind of education received at the Dar al-'Ulum at Deoband (Metcalf 2002, p. 4; citing Mottahedeh 1985).

42 This scene also hints at the maulvi's doctrinal laxity, even hypocrisy, since Tablighis consider watching television haram, especially when members of the movement are involved in dawa. "They should not watch television", Metcalf remarks, "listen to the radio, go to films", all activities adjudged potential distractions from missionary duty (Metcalf 1998, p. 115).

43 "Tablighis", Arsalan Khan reminds us, "uphold and adhere to broader Islamic norms of gender segregation (pardah) in which only men and women who are either married or unmarriageable (mehram) can and should interact" (Khan 2016, pp. 101-2).

44 There is a large body of scholarly literature on the question of the separation of male and female genders in Islam. For an account of the historical roots of contemporary debates, see Ahmed (1992). On this issue and Islam in Pakistan, see Shaheed (2010), and in the United Kingdom, see Jawad and Benn (2003).

45 "Contrary to stereotypical representations of South Asian Muslim women", Aparna Bhar likewise notes in this respect, "Minoo has agency" (Bhar 2014, p. 227). Refusing "a subordinate position because of prescribed gender roles or hegemonic ethnic hierarchies", she continues, Minoo "stands up against her husband ... performs as a partner who shares an intimate laugh with her spouse, a mother who loves and protects her son, a woman who fulfils patriarchal expectations of a religious leader, and one who leaves her husband because she feels he has stopped loving her to return to those who continue to love her" (Bhar 2014, p. 228). 
(Rowena King) informs Parvez not only that Farid and his "people look at you like scum", but also that they had taken a teenaged sex worker "up to the moors" and beat "her all over" (Prasad 1997). Put otherwise, the transformation of the Aziz home into a Muslim activist headquarters compromises relations between host and guests in ways Parvez did not anticipate. On the one hand, the maulvi seeks help from his host in securing British immigration status for his Pakistani family. Echoing Farid's words to Parvez in Fizzy's restaurant, he grounds the request in a doctrinaire articulation of his missionary calling:

I'm in need of some legal advices [sic]. My work is here, so I will stay ... The point is, there are many who reject the teaching. They close their minds and choose atheism. And thinking that bread is all that man needs to live by and that the sky is empty. But right conduct is possible, provided that the preacher advises and warns that in the military industrial state, that the greatness of God's guidance is essential in guaranteeing repentance. Loss of faith in all areas is common here ... (Prasad 1997, 1:09:15-1:10:03)

On the other hand, their numbers continually growing, the cleric and his followers abuse their host's hospitality in contravention of longstanding Islamic traditions concerning the appropriate conduct of guests. ${ }^{46}$ They even appropriate the Aziz marital bed for their own use. Worse, the Punjabi cleric and his followers run up such excessive telephone and utility bills that Parvez fears he will never be able to pay off the mortgage (Prasad 1997, 1:10:18). For the zealous Farid, however, such fiscal concerns seem trivial: "A few pounds is worth it for what we are trying to achieve", he argues, drawing upon his pre-empted training in accountancy to assure his father that the value of the house will rise "once the tarts have gone" (Prasad 1997, 1:10:24-28). Scarcely comforted, the distressed Parvez raises the issue of the beaten teenager, but Farid dismisses the story as "propaganda" and challenges his father for "taking their side" (Prasad 1997, 1:10:30-32). By contrast, behind Parvez's back the maulvi beats a sheepish retreat from the house (Prasad 1997, 1:10:35).

These scenes reveal the extent to which Farid has come to espouse a more uncompromising position on Islamic reform than his mentor, the Punjabi maulvi, whose flight from the Aziz home betrays a sense of shame about the way the group has taken advantage of Parvez. Building upon this disparity, an easily missed exchange between the two proleptically lays the groundwork for the film's climactic events. Downstairs in the house, the camera focuses on the cleric. He is at the centre of the screen, comfortably seated in a lounge chair. Clearly in charge, he issues instructions to his acolytes, who are busy preparing a public demonstration. The maulvi looks directly at Farid, who is displaced to the right of the frame, his back to the camera, pencil and pad in hand, taking notes. Gently wagging an index finger, the cleric expressly orders: "No violence" (Prasad 1997, 1:08:36). Facing the maulvi, still with is back to the camera, Farid echoes the directive: "No violence. No violence" (Prasad 1997, 1:08:38). Things turn out differently, however. Driving Schitz back to the airport in the taxi, Parvez runs into the demonstrators (Prasad 1997, 1:12:53). Stirred up by the young reformers, an angry crowd of Muslims has gathered outside a terraced house tenanted by sex-workers (Prasad 1997, 1:13:38). The mood of the crowd quickly darkens and a demonstrator hurls a Molotov cocktail through an upstairs window of the house (Prasad 1997, 1:14:05). Standing next to one another, Farid and the maulvi

46 As we have seen, Deobandi scholars stress the importance of the hadith and the sunna as guidance for the moral Muslim life. Recognized by Sunni Muslims as the most authentic and authoritative anthology of reports constituting the sunna of Muhammad, the Book of Good Manners and Form [Al-Adab], by Muhammad bin Ismail al-Bukhari (810-70), contains over 7500 sayings in 97 books. It advises that "it is not lawful for a guest to stay with his host for such a long period so as to put him in a critical position" (al-Bukhari 1996, p. 6135). According to Zaman, the Deobandis "gave a new and, in the Indian context, unprecedented salience to the study of hadith in their madrasas ... and have continued to write ambitious commentaries throughout the nineteenth and twentieth centuries" (Zaman 2002, pp. 39-40). Lectures on al-Bukhari's work by "major Deobandi scholar" Anwar Shāh Kashmīrī (1875-1933), for example, were published as Fayz al-Barii ala Sahih al-Bukhari (The Grace of the Creator on the Salih of al-Bukhari) (Zaman 2002, p. 52). Hussein Mohammad Rababah and Yusuf Mohammad Rababah elaborate al-Bukhari's text into twelve obligations incumbent upon guests, including the expectation that visits not be "prolonged and exaggerated" (Rababah and Rababah 2016, p. 51). Drawing upon Mireille Rosello's study of postcolonial hospitality, Copier rightly focuses on "the positions of guest and host" in My Son the Fanatic, but fails entirely to discuss this trope in terms of Muslim tradition (Copier 2005, pp. 95-100; citing Rosello 2001, pp. 167, 175). 
react very differently to this escalation in violence. While the youth pours abuse upon the sex-workers, the cleric stands oddly mute and impassive (Prasad 1997, 1:14:11). Police, who are all Caucasian, attempt to contain the rowdy crowd behind a cordon and lead sex-workers from the burning building. Demonstrators break through the cordon, however, and attack the sex-workers. The maulvi looks on, an almost bemused expression on his face, but Farid rushes forward and assaults Bettina, pushing her to the ground, spitting in her face and calling her a slut (Prasad 1997, 1:14:40). Forcing his way through the rioting mob, Parvez seizes Farid by the scruff of the neck and drags him away to the taxi, as the youth screams, "She's a dirty whore! She's a dirty, filthy whore!" (Prasad 1997, 1:15:09). Parvez forces Farid into the taxi and reverses down the street away from the protest.

Back at the Aziz home, Parvez confronts his son in the latter's bedroom. Barricading the door, he instructs Farid to rid the house of the maulvi's belongings. "If you shame me", the youth answers, "I'm going away, too!" (Prasad 1997, 1:16:30). "Only the corrupt would say it's extreme to want goodness", Farid argues (Prasad 1997, 1:16:39). The confrontation intensifies. Farid challenges Parvez over his father's relationship with Bettina. "It makes me feel sick to have such a father", he cries, accusing Parvez of being "a pimp, who organizes sexual parties" (Prasad 1997, 1:17:09-17). Enraged, Parvez strikes his son. Echoing "My Son the Fanatic", Farid responds: "You call me a fanatic, dirty man. Who's the fanatic now?" (Prasad 1997, 1:17:30). But the film goes further than the short story. Farid spits in his father's face and Parvez crashes his son against a wall (Prasad 1997, 1:17:35). As Minoo forces open the barricaded door and rushes to comfort their son, Parvez leaves the room. Almost immediately, we cut to the living-room downstairs. Minoo demands that her husband not let their son leave. At that instant, Farid rushes from the house (Prasad 1997, 1:19:31). As he strides down the road, a suitcase in one hand, plastic shopping-bags in the other, a rucksack on his back and a duffel over a shoulder, Parvez cruises alongside him in the taxi (Prasad 1997, 1:19:40). Farid ignores his father and turns right up a side-street away from the camera. Three members of the maulvi's group join him, taking up his baggage in solidarity. The four young men walk purposefully up the side-street into the distance. It is the last we see of Farid (Prasad 1997, 1:19:56).

\section{Parvez Aziz and the Sufi Ethos of $I h s \bar{a} n$}

Although the Deobandi maslak gained grassroots adherents only slowly following the founding of Pakistan in 1947, Deobandi teachers already dominated Islamic education in the region. ${ }^{47}$ Parvez was all too familiar with the puritanical pedagogy of the revivalists. As a boy in Lahore, he reveals to Bettina, he was sent by his father "for instruction to the maulvi, the religious man" (Prasad 1997, 00:34:47). Parvez, however, had trouble paying attention in class: the cleric's tone put him to sleep. He infuriated the maulvi all the more "by asking why [his] best friend, a Hindu, would go to kaffir, hell, when he was such a good chap" (Prasad 1997, 00:35:03-10). It is an innocent but loaded question. If a "general political quietude" pervades early Deobandi attitudes towards religious traditions other than Islam, an increasingly "fundamentalist interpretation of Islam ... gradually widened the gap of mistrust between Hindus and Muslims of the subcontinent" (Metcalf 1978, p. 87; Hashmi 2016, p. 140). The partition of the British Crown Raj saw most Hindus flee Pakistan for India, so the Deobandi cleric will have perceived Parvez's unlikely friendship as a particularly egregious aberration for a Muslim boy. ${ }^{48}$ It may also be the case that classroom conventions adopted from British colonial schooling included physical abuse. ${ }^{49}$ Either way, the maulvi responded to the perceived shortcomings of the young Parvez by

47 According to Zaman, by 1960233 of Pakistan's 472 madrasas were Deobandi schools, the majority of them in the Punjab (Zaman 2018, p. 128). In a related vein, Zulqarnain Sewag notes that the Tablighi Jamat's "headquarters are situated in Raiwind near Lahore" (Sewag 2016, p. 331).

48 In "Pakistan and other Muslim majority nations", Jawad Syed writes, "[h]istorically peaceful and tolerant Sunni Muslims (Sufis, Hanafis, etc.) are gradually being exposed to and radicalized by ultraorthodox Salafi and Deobandi ideologies, embracing the twisted notions of takfir and jihad" (Syed 2016, p. 12).

49 Tariq Rahman, for example, reports that well into the 21st century "[s]tudents in Urdu-language schools are ... given corporal punishment for mistakes" (Rahman 2004, p. 309). 
caning him on the arms and legs till he bled (Prasad 1997, 00:35:14). "After such treatment", he tells Bettina, he "said good-bye permanently to next life and said hello to ... work" (Prasad 1997, 00:35:37). It is the chance of "work" that motivated his migration to the United Kingdom, he later reveals, or more precisely: "To feed my family only. I never saw further" (Prasad 1997, 00:54:52-57)..$^{50}$

At the same time, however, if My Son the Fanatic overtly associates Farid's transformation with a doctrinaire form of Deobandi Islam and its attendant expectations and effects, the film couches subtler, but equally arresting changes in Parvez's character in terms of tropes and themes transposed from the Sufi imaginary to the secular world of the postcolonial United Kingdom. While scholars debate the origins of the term "Sufi", Joseph E.B. Lumbard is not alone in claiming that "the individuals most dedicated to the purification of the heart are those historically identified as Sufis, usually defined as the mystics of Islam" (Lumbard 2004, p. 46). 51 This understanding of Sufi life often implies self-denying withdrawal from the hurly-burly of an iniquitous world in redemptive contemplation upon the numinous presence of God. But Sufis have also played more engaged roles in the global dispersion of Islam. ${ }^{52}$ Sometimes accompanying traders and troops, sometimes following in their footsteps, and sometimes merchants themselves, Sufi sheikhs, pirs, and murshids founded residential hospices, or khanqahs. ${ }^{53}$ Famed for manifesting "signs of grace", or baraka, these spiritual masters attracted followers to such community centres, leading to the development of different paths of devotional life, or tariqas. ${ }^{54}$ Erected at the grave of a deceased Sufi master, a shrine, or dargah, became a centre of what Ernest

50 Elsewhere in My Son the Fanatic, Parvez tells Schitz that he moved to the United Kingdom at the same time as his cousin Fizzy, both of whom first worked in a cotton mill (Prasad 1997, 00:05:48 and 00:16:06). After five years, the mill closed and stands abandoned, the site now targeted for redevelopment by the avaricious German businessman. Parvez has been driving a taxi ever since, while Fizzy opened a now highly successful restaurant with five pounds borrowed, ironically, from Parvez (Prasad 1997, 00:05:50). In these respects, the cousins exemplify patterns of migration associated with the Pakistani biraderi, that is, a brotherhood or kinship network. As Sham Arrun-Qayyum writes: "Most arrivals from the Indian Subcontinent-India (Punjab, Gujarat), Pakistan (Mirpur District of Azad Kashmir, Punjab, North West Frontier Province), and present-day Bangladesh (Sylhet and Chittagong)—were not escaping destitution, but were acting out a calculated plan to improve the collective lot of the biraderi" (Arun-Qayyum 2016, p. 47).

51 The term "Sufi", according to Alexander Knysh, "does not seem to have gained wide currency until the first half of the third/ninth century, when it came to be applied to the Muslim ascetics and recluses in Iraq, Syria and, possibly, Egypt" (Knysh 2000, p. 5). Generally, it is assumed to derive from the Arabic suf, which means "wool", thus identifying these ascetics and recluses with their rough woolen robes. Muhammed Hassanali, suggests other etymological possibilities, which include "safa (purity) or safwa (the chosen ones), emphasizing purifying of the heart and the role of divine grace in choosing the saintly ... [as well as] suffa (bench), referring to a group of poor Muslims (contemporaries of the Prophet Mohammad) known as the People of the Bench, signifying a community of shared poverty" (Hassanali 2010, p. 23). Commonly applied to Sufis, certain Arabic epithets sustain this image of austerity, among them abid, or "slave", zahed, or "ascetic", and dervish or faqir, which denote poverty. Some identifiers shed more light on Sufi practices, including arif, or "knower of spiritual truth", salik, or "spiritual traveler", ashiq, or "lover" and wali, or "friend of God" (Hassanali 2010, p. 23). Historically, masters of Sufi spirituality have been known as sheikhs, pirs and murshids, or "guides", and their followers as murids, or "seekers" (Hassanali 2010, p. 23).

52 "Historically", according to Pervez Hoodbhoy, "Sufis were responsible for much of Islam's rapid spread after its initial military conquests in the seventh and eighth centuries" (Hoodbhoy 2016, p. 57). In the following centuries, various Muslim dynasties established and, with varying degrees of success, attempted to sustain Islamic rule in the Levant, Persia and Central Asia; across the Maghreb to the Iberian Peninsula; and in South and Southeast Asia. As Reza Shah-Kazemi argues, though, whatever the degree to which Islam was "spread by the sword" during these centuries, "[t]he mystic and the merchant ... were the most successful 'missionaries' of Islam" (Shah-Kazemi 2004, p. 124). For a concise history of the expansion of Islam and the diverse roles of Sufis in it, see Bloom and Blair (2002). For a comprehensive account, see Michael A. Cook (2010).

53 It is often forgotten that Muhammad himself was a merchant, as were many of his early followers (Knysh 2017, pp. 17, 24-5).

54 "By the fifteenth century", writes Ira M. Lapidus, "throughout the Islamic lands the common people were ordinarily both the clients of schools of law [madhhab] and members of one or another Sufi brotherhood [tarīq]", which together became "the backbone of Muslim community organization" (Lapidus 1996, pp. 14-5). Framing their teachings and practices in terms of a distinct spiritual genealogy, or silsila, and chains of authoritative hadith interpretation, known as isnad, major tariqas like the Qādiriyya, the Suhrawardiyya, the Shädhiliyya or the Naqshbandiyya traced a lineage of leaders back to Muhammad himself, usually by way of Ali ibn Abi Talib (601-661), the prophet's cousin and son-in-law, who ruled as Islam's fourth caliph from 656 to 661. The Qadiriyya is named for 'Abd al-Qadir (1077-1166), who founded the tariqa in Baghdad in 1119. Associated with Abū al-Najīb 'Abd al-Qahir al-Suhrawardi, (1097-1168) and his nephew Shihāb al-Dīn 'Umar Suhrawardī (1145-1234), the Suhrawardiyya tariqa originated in Baghdad around 1200. Abu 'l-Oasan 'Ali al-Shādhili (1196-1258) established the Shādhiliyya tariqa in Alexandria, Egypt, about 1250. The Naqshbandiyya tariqa took the name of Bahā' al-Dīn Naqshband Bukhari (1318-89), who oversaw a spiritual retreat in Bukhara, Uzbekistan, in the early fourteenth century. For details on these tariqas, see Knysh (2017, pp. 170-244). 
Gellner calls "the Low Islam of the people" or "Folk Islam" (Gellner 1992, pp. 9, 15)..$^{55}$ Sufi teachings thus permeated the everyday mores of local communities. ${ }^{56}$ Central to these teachings is the notion of $i h s \bar{a} n$, which "means making beautiful or good, or doing what is beautiful or good" (Lumbard 2004, p. 41). ${ }^{57}$ "The ihsān intellectual tradition", Lumbard continues, "begins with the teachings of the Qur'ân and the Prophet Muhammad, who told his companions that 'God has ordained ihsān for everything'" (Lumbard 2004, p. 41). It is the Sufi tradition, though, that focuses most intently upon "the practice of $i h s \bar{a} n$... where the emphasis is on making one's heart and soul beautiful so that beauty will arise naturally from within" (Lumbard 2004, p. 41).

In the words of Peter van der Veer: "The expansion of Sufi brotherhoods was a crucial aspect of the Islamization of South Asia, since Sufism was largely coextensive with Islam until the nineteenth century" (Van der Veer 1994, p. 34). ${ }^{58}$ Sufis exercised particular influence in the north and northwest of the sub-continent. By the 18th century, Sufi sheikhs in Sind and Punjab enjoyed notable advantages over the scholarly ulama in dealings with the Mughal court because "they already had regional power bases linked to sacred shrines" (Bowen 2016, p. 27). ${ }^{59}$ During the British Crown Raj, however, conservative reformers at the Dar al-'Ulum at Deoband responded to the declining political status of Islam, especially of Islamic law, or shari' $a$, by reconstructing the Sufi practices associated with folk Islam as

55 Martin van Bruinessen notes, for example, that across North Africa and in South and Southeast Asia "monistic" Sufi teachings were not incompatible with a variety of "conceptions of immanent godhead, and easily merged with older local beliefs and practices" (Van Bruinessen 2009, p. 139). That is to say, Sufis have invariably tolerated and adapted "to local customs and traditions, and Sufi orders have incorporated what ... are commonly called 'popular' beliefs and practices" (Van Bruinessen 2009, p. 145). It is true, as William C. Chittick has observed, that in later centuries Muslim commentators scapegoated Sufis for "Islam's 'backwardness'" when confronted with the scientific and technological advances accompanying European colonial and imperial incursions into traditionally Islamic lands (Chittick 1995, p. 107). For liberal and conservative Muslims alike, Chittick ventriloquizes, "Sufism is the religion of the common people and embodies superstition and un-Islamic elements adopted from local cultures; in order for Islam to retain its birthright, which includes modern science and technology, Sufism must be eradicated" (Chittick 1995, p. 107). But in many parts of the Dār-al-Isläm, or "Abode of Islam", the persistence of the Sufi ethos of ihssān among Chittick's "common people" continued to sustain the moral and spiritual character of Muslim life at the grassroots level into the 19th and 20th centuries.

56 Hassanali notes that Sufis cultivated "the ethical responsibility to return to community life, fulfill the obligations of Muslim life and to display the impact of divine experience" (Hassanali 2010, p. 25). In the medieval period especially, Sufi adepts emphasized "the practical and moral aspects of Sufism and carefully eschewed its more intellectualizing expressions" (Knysh 2000, p. 171).

57 Knysh describes ihsān as "the state of spiritual perfection ... that comes on the heels of the state of external submission [to God's will] (islām) and that of internal faith (imān)" (Knysh 2000, p. 321).

58 As early as the eighth century "[c]oastal trade and the presence of a Muslim community in Sind facilitated significant cultural exchanges and missionary activity which brought Sufism in its wake" (Hassanali 2010, p. 26). By the tenth century, Sufi influence had spread from Persia through Afghanistan to Sind and the Punjab. "Most of this activity occurred in western Punjab", remarks Hassanali, "and was carried out primarily by the Chishti and Suhrawardy Sufi orders" (Hassanali 2010, p. 31). "An extensive network of khanaqahs", Hassanali writes, "became an important institution of Muslim and non-Muslim community life in medieval India" in large part because of "the spiritual, social welfare, educational, and cultural functions they performed for the local population" (Hassanali 2010, p. 27). In a related vein, Metcalf observes: "In the early centuries of [pre-Mughal] Muslim rule [in India] (that is, in the thirteenth and fourteenth centuries A.D.), the Sufis were the dominant religious figures-teaching, writing, and mediating between their followers and the government and between rival claimants to political power" (Metcalf 1982, p. 18). During the Delhi Sultanate (1206-1555), the supervision of dargahs as popular devotional sites and khanqahs as centres of charitable, educational and cultural activity secured Sufi tariqas sympathetic attention from a succession of Turkic and Afghani dynasties. "By the sixteenth century", writes Bowen, "a number of Sufi orders were localized in lodges" (Bowen 2016, p. 26). From the later 1500s, the economic, social and political status thus gained afforded Sufis compelling influence with successive Mughal emperors. Indeed, according to Knysh, "[t]he heyday of the Indian țarīqas falls on [sic] the Moghul period" (Knysh 2000, p. 282).

59 As Muhammad Hassanali notes, "the pirs [were] a formidable force wielding enormous political, economic, and spiritual influence over large numbers of their disciples who resided primarily in villages" (Hassanali 2010, p. 34). 
“a moral scapegoat" (Ingram 2009, p. 480). ${ }^{60}$ By the middle of the 20th century, more activist Salafi or Wahhabi influences upon Deobandi and Tablighi thinking led to their viewing as idling or idolatry popular Sufi practices like music and dance, ecstatic immoderacy and the veneration of deceased Sufi masters at cultic shrines (Ingram 2018, p. 21; Metcalf 1978, p. 16). ${ }^{61}$ In recent decades, Deobandi antagonism towards Sufi folk traditions has been especially pronounced in Pakistan. ${ }^{62}$ At the same time, however, other Islamic movements have adopted a more sympathetic attitude towards Sufi practices in the sub-continent and beyond, most notably the Barelvis. ${ }^{63}$ Founded in 1904 in Bareilly, Uttar Pradesh, by the Qādiriyya Sufi scholar Ahmed Raza Khan (1856-1921), the Barelvis installed themselves in several important northern South Asian centres, including the madrasa Hizbul Ahnaf, which opened in Lahore in 1924. In this last respect, Lahore's Data Darbar enjoys preeminent status as the largest Sufi shrine in South Asia. ${ }^{64}$ The Barelvis also played a key role in the founding of an independent Pakistan, though relations between the sect and political power have been mixed. ${ }^{65}$ Despite the efforts of successive Pakistani governments to modernize the cult of shrines like the Data Darbar, for example, the sajjadah nishins

60 It is worth noting that the Punjab Land Alienation Act (1900) helped to align the interests of the Sufi pirs with those of the British Crown Raj by bestowing privileged status upon the former as a kind of "landed gentry" (Hassanali 2010, p. 34). To be sure, the Deobandis still acknowledged the basic Sufi insight that true spiritual wisdom and personal morality went hand in hand, and as such the sect continued to cultivate charismatic leadership and to maintain tariqas and khanqahs. As Reetz has noted, "Deobandi divines were themselves active Sufi sheikhs, following the path, or tariqa, where they saw it in consonance with the law and word of God, or Sharia" (Reetz 2007, p. 140). "In general", remarks Metcalf, "allegiance to the Chisht order predominated at the school" (Metcalf 1978, p. 118). For a detailed account of "Deobandi Sufism", see Metcalf (1982, pp. 157-97). Similarly, though members of the kindred Tablighi Jama'at may not always have pledged formal allegiance to a Sufi master, they often maintain the Sufi devotional practice of dhikr, or "remembrance", using beads to count prayers, and the movement's preference for working in groups draws upon "the Sufi model of Islamic companionship" (Horstmann 2009, p. 42; Khan 2016, p. 105). Gaborieau, on the other hand, disputes any easy association between Tablighi Jama'at and Sufi traditions. He acknowledges that "the founding lineage shares a common line of initiation, is endowed with Sûfî charisma and teaches the members some Sûfi practices", but he concludes that "the esoteric individual quest and its ecstatic complement, which characterize Sufism, do not constitute an integral part of the Tablîghî agenda" (Gaborieau 2006, pp. 21, 47). Likewise, Thomas K. Gugler writes that "Tablighis preach a purified Islahi-Islam" and "reject 'later' rituals, in particular Sufi practices, which they condemn as reflecting Hindu influence" (Gugler 2010, p. 126).

61 This "gradual politicization", Naeem argues, "resulted in a form of Deobandism which is akin to a militant Wahhābism ... quite removed from the traditional Sufi piety of the founders of Deoband" (Naeem 2004, p. 114). At the same time, Naeem proposes that "Deoband's opposition to certain popular Sufi practices needs to be seen not as puritanical reform, but rather as an attempt to focus on essential Sufism" (Naeem 2004, p. 93). Put otherwise, as Reetz remarks",Sufism was acceptable to South Asian reformist Muslims if it was the 'right' Sufism, based on the shari'a, on the Qur'an and the Sunna and did not follow heretic practices" (Reetz 2006, p. 35). "[I]n right measure and form", Reetz continues, the Deobandis viewed Sufi traditions "as an indispensable element of true Islam shaping a moral and pious character, a necessary supplementation for theological students, but also for salvation in general" (Reetz 2006, p. 35). In this respect, Naeem argues that the Dar al-'Ulum at Deoband "sought to replace popular Sufism with a more sober, law-bound, and intellectual Sufism" (Naeem 2004, p. 93). By contrast, Bowen has remarked that Deobandi educators "combined the two Islamic roles of the scholar and the sheikh: the person so knowledgeable in Islamic legal sciences that he could dispense a legal opinion, and the person so adept in the pursuit of mystical knowledge through a Sufi path that he may lead a local Sufi lodge" (Bowen 2016, p. 28). Likewise, Sidat maintains that for the Dar al-'Ulum at Deoband "Sufism ... was closely integrated with Hadith scholarship and legal practices in Islam" (Sidat 2019, p. 4).

62 "During the second part of the twentieth century", Gugler writes, "Deobandis increasingly propagated an anti-tarīqah (Sufi method) and anti-Sufi message, targeting in particular systems of shrine-centred Islamic authority" (Gugler 2016, pp. 389-90).

63 Syed argues quite explicitly that Ahmed Raza Khan founded the Barelvi movement "as a safeguard against Wahhabi-inspired Deobandi literalism in South Asia" (Syed 2016, p. 232). Similarly, Naeem writes that the Barelvis "fought to preserve Sufism as it was traditionally and popularly practiced in India, from attacks by both modernists and reformers as well as from other Sufi schools like the Deobandīs" (Naeem 2004, p. 93). Unlike the Deobandis, though, the Barelvis failed to establish an extensive network of madrasas across the British Crown Raj (Jackson 2013, pp. 151-52).

64 The Data Darba was built in the 11th century to commemorate the Sufi wali Syed 'Alī al-Hujwīrī (1009-1072). Patron saint of Lahore, al-Hujwīrī is celebrated for a comprehensive account of Sufi doctrines and practices known as the Kashf al-mahjūb [Unveiling of the Hidden] (1074). Symbolizing "the 'wedding' of the wali's soul with Allah", the Data Darbar's annual urs [literally "marriage"] festival commemorating al-Hujwīir's death is "one of the biggest religious gatherings in the Pakistani calendar" (Hassanali 2010, p. 30; Philippon 2012, p. 292). Equally importantly, the shrine meets more material needs. Dozens of stalls around the site offer employment, while the Data Darbar's "provision of food, water, sanitation and other services have made it an outstanding center for deprived sections of society" (Strothman 2016, p. 232).

65 "Within the context of pre-Partition politics", William Kesler Jackson has argued, "[the Barelvis] had, by and large, fought for the establishment of an Islamic state, complete with a constitution that they would have a hand in designing ... and a government that they would help lead as the spiritual guides of the Sunni majority" (Jackson 2013, p. 292). Similarly, Riffat Hassan observes that Muhammad Iqbal (1877-1938), considered the progenitor of the "Two Nation Theory" that led to the creation of the independent dominions of Pakistan and India, "sought to reform contemporary Sufi thinking and practices in the light of his understanding of the Qur'anic perspective of the relationship of humanity to God and creation" (Hassan 2017, p. 6). "Iqbal's ideal person does not retreat from the world", continues Hassan, "but regards it as the training ground for spiritual development" (Hassan 2017, p. 7). In a related vein, Joseph Hill writes: "In the run-up to Pakistani partition in 1947, the Deobandi political organization Jamiat Ulema-i-Hind opposed partition, while Barelvis overwhelmingly supported it” (Hill 2019, p. 14). 
[Sufi hereditary administrators] continue to manage their religious affairs and to dispense moral and spiritual wisdom (Hassanali 2010, p. 42). More generally, however, whatever the vicissitudes of Pakistan's recent political history, Muhammad Hassanali asserts that "Sufism in many different local forms persists and survives across the entire population spectrum from the illiterate to the elite" (Hassanali 2010, p. 43). ${ }^{66}$

Although Parvez tells us in My Son the Fanatic that he suffered abuse as a youngster at the hands of a Deobandi maulvi, it is the social and cultural environment of Sufi folk Islam that will have shaped his upbringing in Lahore either side of the founding of the new dominion of Pakistan in 1947. At the same time, as Wright observes, the film mediates "Farid's religion in piecemeal fashion through Parvez's perspective", and in so doing "positions the viewer with Parvez" (Wright 2007b, p. 111). "Since [Parvez and the viewer] each stands outside the world into which Farid is moving", she continues, "audiences are encouraged to empathise with his father, co-observers of the process" (Wright 2007b). Understood from Parvez's point of view, My Son the Fanatic therefore portrays a world filtered to a greater or lesser degree through the more capacious lens of Sufi folk Islam. In general terms, for example, Parvez's fondness for jazz and rhythmand-blues echoes historical Sufi adaptations of popular South Asian secular music, while his status as an immigrant taxi-driver recalls Sufi tropes of the journeyer and the guide. ${ }^{67}$ More importantly, though, the Sufi ethos of ihsān permeates the development of Parvez's character, in particular the blossoming of his love for Bettina. Three sequences in the film invite particular attention.

The first sequence begins with Parvez driving Bettina and a boorish drunken client to the latter's hotel. She is dressed "professionally", all in black, with long blonde hair and bright pink lipstick. After helping her deal with the inebriated client, a thoughtful Parvez not only informs Bettina that he has recommended her to Schitz, but also offers to wait to take her home after this "all-night job" (Prasad 1997, 00:07:41-49). With dawn breaking over a bleak post-industrial cityscape, Parvez and Bettina share fast food at a mobile stand. She cajoles Parvez into taking her to "a place"; "I need the air", she says (Prasad 1997, 00:09:17-20). This "place" bears no visual resemblance to the mundane urban spaces, both domestic and public, that we have so far entered in My Son the Fanatic. Bettina leads Parvez across a pastoral landscape of gently rolling hills to hillier pine woods lushly carpeted with primordial ferns. Shades of green dominate the screen. For Sufis, as Annemarie Schimmel notes, "green has always been considered the highest and heavenly colour" (Schimmel 1978, p. 256). ${ }^{68}$ Looking down through the trees from the top of a hill, a songbird chortling in the background, the camera catches Parvez struggling up a thickly treed slope, then reverses the shot (Prasad 1997, 00:9:52-10:00). ${ }^{69}$ From Parvez's point of view, a deep-focus take depicts Bettina standing in a ruin at the top of the hill, framed by a

66 Demographics bear out this assertion. In the 1960s and 1970s, according to Syed, "Sunni Sufis and Barelvis are estimated to be 50-60 percent of the Muslim population in Pakistan in contrast with 15-20 percent Deobandis, 15-20 percent Shias and 5 percent Ahl-e-Hadith or Salafis/Wahhabis" (Zaman 1999, p. 128; Syed 2016, p. 231).

67 If Deobandis rejected music and dance as haram, Mikko Viitamäki writes of the popularity of the arts in the sam $\vec{a}$ [ritual listening] of the Chishtiyyah, historically the most influential Sufi order in South Asia. "Music and poetry performed in sam $\bar{a}$ ", he observes, "developed into refined and polished arts and aptitude for appreciating their effect became a virtue of a Sufi disciple" (Viitamäki 2017, p. 592). Indeed, Ayyaz Gull asserts that "no festive activity could be completed in colonial Punjab, particularly among Chishti Sufis, without the mystical concert or devotional song (sama)" (Gull 2018 , p. 50). That said, such practices were "highly ambivalent", there being "nothing in the music and poetry performed in sam $\vec{a}$ that would have automatically made the listeners associate them with a spiritual framework instead of, for example, human romance" (Viitamäki 2017, p. 605). In a related vein, Hassanali remarks on the variety and adaptability of Sufi musical idioms, "which take on different regional forms in accordance with local traditions" (Hassanali 2010, p. 24). As Seyyed Hossein Nasr notes, for example: "In India and Pakistan, Sufis and even non-Sufis with some spiritual proclivity listened to qawwwāli and khayāl singing, as well as rāgs, which were taken from Hindu music and Islamicized" (Nasr 2007, p. 146). Sufis as journeyers and guides are ubiquitous tropes in the scholarly literature. "Reading Sufi history through $\bar{a} d \bar{a} b$ ", for example, Lloyd Ridgeon identifies "normative Sufism" with the themes of "purity, self-denial, control of the nafs [ego], travelling, the need to follow a guide, and specific body coverings" (Ridgeon 2017, p. 393).

68 More specifically, Ahmad Y. Ghabin remarks that "green color symbolizes on the one hand the renewal of life earth and the goodness of God, and the other the continuity and eternity of life in Paradise, abundant with vegetation and flowing rivers" (Ghabin 1998, p. 195).

69 Annemarie Schimmel notes that in the work of Sufi poets Manșūr al-Hallāj (858-922) and Farīd ud-Dīn Atțār (1145-1221), birds and birdsong often symbolize the soul (Schimmel 1978, pp. 70, 306-8). In other Sufi poetry, birds may signify divine grace or purity (Schimmel 1978, pp. 126, 232). 
stone arch, a medieval English adaptation of an archetypal Islamic architectural feature (Prasad 1997, 00:10:01). ${ }^{70}$ Bettina is still dressed all in black and now wears vivid red gloves, colours respectively symbolizing gnosis and love in South Asian Sufi traditions. ${ }^{71}$ Parvez enters the mise-en-scène from the right. Over his shoulder, the camera captures him in the foreground looking up at Bettina, her arms extended like an angel's wings in Sufi iconography (Prasad 1997, 00:10:04). "It's magnificent", he shouts (Prasad 1997, 00:10:09). Then, casting his gaze 'east', as it were, beyond the frame to the right, Parvez recalls, "There were places back home I used to go", explicitly connecting the English ruin with Pakistan's Muslim landscape (Prasad 1997, 00:10:15). He turns to look back down the hill, but in so doing blocks our view of the arch. Wistfully, he finishes his thought: "With a girl actually" (Prasad 1997, 00:10:20). The camera looks beyond Parvez back up at the arch. Bettina has disappeared. As if by magic, in a reverse shot, she then reappears just below Parvez on the slope, her black garb and red gloves vibrant amidst the greens of the woodland (Prasad 1997, 00:10:26-37).

At the same time, however, a playful humour informs the closing frames of this woodland sequence, preventing us from taking the Sufi iconography literally. A long shot shows Bettina and Parvez crossing a stream. At first, we are reminded once more of Islamic visions of paradise, upon which Sufi writers have elaborated at great length. "It is", in Nerina Rustomji's words, "a realm of fountains and rivers filled with ease in contrast to earthly life" (Rustomji 2010, p. 170). ${ }^{72}$ But a shot over Bettina's shoulder follows. Comically inept, Parvez slips on a rock into frigid waters (Prasad 1997, 00:10:47-55). In mock shock, he shrieks "icicles going inside" (Prasad 1997, 00:10:56). Bettina laughs. "Those trousers will have to come off", she says, as she leads him from the woods (Prasad 1997, 00:11:00). As Bettina mischievously, if ironically reverts to the role of sex-worker, Parvez's adventure seems to be over. Significantly, though, its fuller meaning evolves in the next sequence. The film cuts to the interior of the Aziz home. Minoo is performing household chores. Without mentioning Bettina, Parvez tells her about the adventure in the woods: "I saw a strange building which reminded me of the ruin near your grandfather's house in Multan" (Prasad 1997, 00:11:40-42). Doubtless, the arched "ruin" in Multan to which Parvez refers is an Islamic site; southwest of Lahore in Pakistan's province of Punjab, this "City of Saints" and the eponymous region are celebrated for their numerous Sufi shrines. ${ }^{73}$ Doubtless, too, Minoo is the "girl" whom Parvez nostalgically places in this sacred setting. Clearly moved by the memory of a happier time, Minoo gently asks him to take her to the "strange building". He turns away, wounding her with a hurtful silence, his face in a glass of whisky (Prasad 1997, 00:11:54). If the English arch reminds Parvez of salad days "with a girl" in a South Asian Sufi landscape, those feelings are now associated not with her, but with Bettina, dressed in black, an alluring figure with red-tipped arms outstretched like angel's wings, mysteriously able to disappear and reappear in the green woodlands of rural England.

70 There are numerous studies of the varieties of arch in Islamic architecture. For a succinct account, see Rahman (2015). For the arch in South Asian Islamic architecture, see Brown (2004). For an analysis of European uses of the architecture of Islamic arches, see Draper (2005).

71 According to Schimmel, the Kubrāwiyya order "developed an elaborate color symbolism", associating "red" with "gnosis" and "black" with "passionate love and ecstatic bewilderment" (Schimmel 1975, p. 256).

72 The Qur'an contains numerous references to the rivers of paradise. Controversial for the promise of wine, one reads: "A description of the Garden promised to the righteous: Therein are streams of water which corrupts not; and streams of milk of which the taste changes not; and streams of wine, a delight to those who drink; and streams of clarified honey" (Qur'an 45, p. 15).

73 Writing about "the history of Sufism in Multan", for example, Muhammad Touseef and Alexandre Papas highlight "the existence of unconventional members of the medieval Suhrawardiyyah; the emergence of the Qãdiriyyah order and its great development over the long duration; the renewal of the Chishtiyyah from the eighteenth century onwards, especially from the point of view of its intellectual production; the survival, according to a particularly varied typology, of marginal Sufis which are still the object of veneration today" (Touseef and Papas 2019, p. 495). Several times, Touseef and Papas invoke the moniker "City of Saints" for Multan (Touseef and Papas 2019, pp. 472, 482, 496). 
Establishing a tacit bond between Parvez and Bettina, this idyllic episode lays the groundwork for his first visit to her home-the second significant event featuring the pair. Here, in the same sequence in which Parvez tells the tale of the bullying Deobandi pedagogue, we gain some insight into his moral character. Recalling Sufi folk Islam, verbal and visual cues establish a thematic context for this revelation. Parvez delivers alcohol to Schitz's suite at the Pennington Midland Hotel, but his words and look clearly indicate concern as Bettina snorts what she describes as "good coke", an opinion which the German businessman generalizes into a casually blasphemous judgment upon the whole community: "Thank God there's something good in this town" (Prasad 1997, 00:32:04-07). As she heads to the bedroom, however, an intoxicated Bettina hands Parvez a long-stemmed red rose. In western cultures generally, the red rose symbolizes love and vitality, but the flower holds a special place in Islam, too, particularly among Sufis. ${ }^{74}$ As Schimmel notes of the trope in the work of pre-eminent Sufi poet Jalāl ad-Dīn Muhammad Rūmī (1207-1273), "the rose, in its absolute perfection, was known as the flower representing the beloved; ... a sign of Divine grace ... [it] reminds man of the garden of paradise, of creation and resurrection; it allows a first glance on divine beauty, and hides this beauty again with a colorful veil" (Schimmel 1978, pp. 90, 92, 93). A rose on a thorny long stem, moreover, represents the ambiguities of love's existential vicissitudes: "the thornlike lover in all his destitution belongs to the rose-like beloved", even as "the thorn boasts of its sharp weapon by which it protects the lovely rose against the host of its enemies" (Schimmel 1978, p. 92).

Just as importantly, these scenes associate Bettina with the symbolism of light, even when she is serving the avaricious Schitz. The German businessman dismisses Parvez, pushing him from the hotel suite, non-plussed with rose in hand. Outside the hotel, Parvez attends to the signal light on the roof of the taxi; it had started to misbehave after he followed Farid and his cohort to the mosque (Prasad 1997, 00:27:43). The light flickers and explodes. In words which might also be taken as a punning censure of Schitz, Parvez curses: "Shit. Damn it" (Prasad 1997, 00:33:08-26). If the taxi now lacks a guiding light, however, Parvez turns to gaze almost longingly at the brightness emanating from the window of Schitz's hotel suite, where Bettina continues to conduct her business as a sexworker (Prasad 1997, 00:33:39). In the next scene, the camera follows the taxi's headlights, as Parvez ferries Bettina home (Prasad 1997, 00:33.42-46). At her house, Bettina thanks Parvez, affectionately strokes his face and exits the taxi. He sits pondering the situation, then decides to go after her, leaves the taxi and walks towards the house, calling out her name. In the foreground, the camera captures a brightly illuminated red telephone box, as a light goes on in a window of Bettina's home. Parvez stops and gazes up in contemplation of the light (Prasad 1997, 00:34.13-28). In the Sufi tradition, light, or nur,

74 The association of the red rose with love in western culture is perhaps captured most succinctly in the lyric "My Love Is Like a Red, Red Rose" (1794), by Scottish romantic poet Robert Burns (1759-96). In addition to Sufi poetry, according to Hamid Shirvani, "[t]he rose probably was the most important and revered flower" in Persian Sufi garden design, the principal inspiration for the Mughal gardens of South Asia, including the Shalamar Gardens of Shah Jahan [Shahab-ud-din Muhammad Khurram] (1592-1666) in Parvez's home city of Lahore (Shirvani 1985, p. 27). For studies of the sub-continent's Mughal gardens, see Wescoat and Wolschke-Bulmahn (1996). In another context, Muslims in Pakistan often scatter rose petals over the bodies of deceased family members and offer roses at the shrines of Sufi pirs. See, for example, Black (2003, pp. 9, 15) and Ernst and Lawrence (Ernst and Lawrence 2002, p. 93). By contrast, Parvez invokes the figure of the rose to inadvertently reveal the decadent state of the contemporary United Kingdom. Driving Schitz through the red-light district on the way from the airport to his hotel, he comments: "Local people and religious types don't like. Condom and all, you know, hanging from the rose bushes" (Prasad 1997, 00:05:14-22). 
symbolizes “God's luminous presence in the empirical universe" (Knysh 2017, p. 66). ${ }^{75}$ More specifically, as Schimmel writes, "only the light of gnosis [wisdom of the heart], the light of certainty gained through intuitive knowledge, could help in approaching the mystery of love" (Schimmel 1975, 140). From Parvez's point of view, My Son the Fanatic reflects this symbolism as he approaches Bettina's home.

Leaving Parvez gazing up at the light from Bettina's house, the film cuts to its interior. He has come inside. As they chat, Bettina recognizes his concern for Farid, but reveals her interest in Parvez, too: "You talk about the lad a lot, but you never talk about yourself. I had all these questions I've wanted to ask you" (Prasad 1997, 00:35.45). Parvez tells her about the abusive Deobandi maulvi, but then Bettina turns the conversation back to Farid:

Bettina: But you can't blame the young for believing in something beside [sic] money. You've got to give Farid a better philosophy.

Parvez: What type?

Bettina: I don't know. How do you feel about things? The purpose of life, all that. How we should treat each other.

Parvez: Good, I think, where possible. But I can't explain the origin of universe. (Prasad 1997, 00:35.45-36.14)

For Bettina, "a better philosophy" has to do with how we "feel" about the way "we should treat each other", that is, with ethical insight analogous to the sort of gnosis or "intuitive knowledge" Schimmel identifies with Sufi teaching. Prompted for his view, Parvez implicitly agrees. Cosmological speculation about "the origin of the universe" may be beyond him, but he draws upon the ethical conventions of Sufi folk Islam which will have suffused the everyday life of his earlier years in Lahore. This upbringing prompts a simple reply to Bettina: "Good, I think, where possible." In Lumbard's words, "the Sufis saw themselves as that group among the scholars who were especially devoted to the science of doing beautiful or doing good (ihsān)" (Lumbard 2004, p. 53). Parvez's youthful friendship with a Hindu boy, for example, epitomises this quality. As Syed notes, "Barelvis and other traditional Sufis have shown an inclusive and non-violent approach to other sects and faiths" (Syed 2016, p. 234) ${ }^{76}$ Now, in the postcolonial United Kingdom, the simple phrase "Good, I think, where possible" captures the existential essence of this Sufi ethos, in stark contrast to the intolerance of Parvez's boyhood Deobandi teacher, which later appears reformulated on a global scale in the Punjabi maulvi's criticism of "the military industrial state" and still more vehemently in the zealousness of Farid's racist and anti-Semitic attack

75 Gerhard Böwering, for example, refers to the Sufi poet Pseudo-Ja'far as-Sadiq (702-765), who "enumerates different types of light ... found in the believer's heart", including "the light of introspection, fear, hope, love, meditation, certitude, recollection, knowledge, shame, faith, Islam, good works, blessings, graces, benefits, generosity, compassion, prudence, awe, perplexity, life, intimacy, steadfastness, humility, tranquility, majesty, splendor, power, beauty, justice, strength, divinity, oneness, unicity, endlessness, everlastingness, eternity, beginninglessness, permanent subsistence, wholeness and divine He-ness" (Böwering 2001, pp. 135-36). Ultimately, Sufis trace the symbol of light to the celebrated "Verse of Light" in the Qur'an:

Allah is the Light of the heavens and the earth.

The example of His light is like a niche with in which is a lamp,

The lamp is within glass, the glass as if it were a pearly [white] star,

Lit from [the oil of] a blessed olive tree,

Neither of the east nor of the west,

Whose oil would almost glow even if untouched by fire.

Light upon light.

Allah guides to His light whom He wills.

And Allah presents examples for the people,

and Allah is Knowing of all things (Qur'an 24:35).

For an analysis of Sufi interpretations of this verse, see Böwering (2001). For readings of the symbolism of light in Sufi writings, see Schimmel (1975).

Dominant in Pakistan, for example, the Chishti tariqa has long manifested "tolerance and openness to spiritual exchange and inter-religious cooperation", even appropriating "Hindu rituals such as rubbing with sandalwood paste that were transferred from ceremonies surrounding idols to ritual veneration of Sufis saints' graves" (Hermansen 2008, p. 161). 
on his father at dinner in Fizzy's restaurant. At the same time, of course, Parvez's use of the word "good" suggests an ironic contrast in values with the hedonistic amorality embodied in Schitz's judgment that "good coke" is the only "good" thing to come out of the local community.

The scene in Bettina's home closes, and as Parvez departs the camera catches the sun symbolically bringing a new day to the darkened city. "Hey, call me Sandra when we're alone", Bettina tells Parvez, capturing the aura of authenticity that pervades the whole sequence. ${ }^{77}$ "This is the password, yeah, to you?" Parvez replies, confirming in secular terms the gnostic nature of their relationship (Prasad 1997, 00:36.26-29). Sealing their deeper connection, Sandra, that is, the true Bettina, kisses him softly on the lips: "I don't know when I last kissed a man" (Prasad 1997, 00:36.47-52). ${ }^{78}$ Possessed of the "password" to Sandra, however, Parvez faces a difficult transition from a past love now faded into an unknown future. Couched once again in Sufi iconography, a third sequence involving Sandra brings Parvez to her home for a second time and, in so doing, helps to clarify this unknown future. The visit is not intended. Parvez simply plans dinner with Sandra at Fizzy's restaurant. In his basement 'man-cave', he readies himself for the date. Rife with ambiguities, the scene reflects prime themes in the film. Parvez dons a smart suit but lies to Minoo that it is Schitz who expects him "to dress well" (Prasad 1997, 00:51:15). At the same time, he queries his wife's tolerance for the maulvi, criticizes Farid and the cleric for "[1]aying down the law for other people", and playfully threatens to "tug" the maulvi's beard to "see what is underneath" (Prasad 1997, 00:51:22-35). The gag makes Minoo giggle, the only time in the film we see her happy (Prasad 1997, 00:51:22-35). Dancing a little jig to "A Rockin' Good Way" (1958), sung by African-Americans Brook Benton (1931-1988) and Dinah Washington (1924-1963), Parvez deliberately turns up the volume to annoy Farid and the maulvi upstairs. Sub-titled "Mess around and Fall in Love", the rhythm-and-blues classic at once reflects Parvez's adulterous deceit and suggests a romantic mood for his tryst with Sandra.

At the restaurant, however, things do not go as expected. Aware of Sandra's alias as Bettina the sex-worker, Fizzy refuses to seat the couple in the main dining-room and relocates them to an unused annex. The embarrassment turns fortuitous. As atmosphere of harmony pervades the unanticipated privacy of the annex, as affinities come to light. We are already aware of Parvez's fondness for jazz and rhythm-and-blues. Now Sandra reveals that she is taking singing classes, while Parvez recalls that "[i]n school [he] loved the hymns" (Prasad 1997, 00:53:46-53). ${ }^{79}$ They learn that their biographies are similar in larger ways: Parvez migrated to the United Kingdom "to feed my family only", while Sandra "wanted to be a teacher" till the premature death of her "man" forced her into the sex trade to support her children (Prasad 1997, 00:54:52-55:13). When Fizzy shatters the harmony with questions about Farid's engagement party, the couple depart the restaurant. The film cuts to Sandra's home (Prasad 1997, 00:54:39). At first, things do not go well, as Parvez queries the amount of time Sandra is spending with Schitz. She angers when quizzed about bruises the German has given her and tells him to leave if he does not like what he sees. But then she challenges him: "You like me today, don't you? Because sometimes you're not

77 Arguing for an "opposition between public and private" roles, Copier quite wrongly asserts that "Bettina wears a blonde wig, whereas Sandra is a brunette" (Copier 2005, p. 93). Rather, Sandra's naturally blonde hair is cropped short, perhaps so that her wig of longer blonde hair affords a more convincing and comfortable disguise for her alias 'Bettina.'

78 The idyllic woodland setting through which Bettina earlier guided Parvez implies, of course, that the persona of the sex-worker is not her truer self. Sufi anthropology is helpful here. As Schimmel writes, in our efforts to transform conditions of temptation and turmoil into conditions of virtue and tranquillity, we are engaged in a "constant struggle against the nafs, the 'soul' - the lower self, the base instincts, what we might render in the biblical sense as 'the flesh'" (Schimmel 1975, p. 112). Called by Sufis "the greater holy war [al-jihād al-akbar], she continues, this struggle requires us "to purge the nafs of its evil attributes in order to replace these by the opposite, praiseworthy qualities" (Schimmel 1975, p. 112). Put otherwise, Sandra aspires to redeem 'Bettina' from the lifestyle which adverse circumstances have obliged her to adopt in order to survive. Supporting children factors in here, too, though My Son the Fanatic neither tells nor shows us anything about them except a small framed photograph which Parvez ponders on this first visit to her home (Prasad 1997, 00:34:28).

79 Conversely, Parvez confesses that he forced Farid to study "science and maths" instead of "music and arts and all", his son's preference, and so "caused resentment" (Prasad 1997, 00:53:56-54-06). 
so sure. Do you know why you like me?" (Prasad 1997, 00:56:46-7:07). Forcing Parvez to reflect, the challenge provokes an open exchange of mutual affection between the couple, captured in a series of shots and counter-shots.

First, the camera focuses on Parvez. Almost in tears, he describes his feelings for Sandra:

It's only that I can't help thinking ... that you are a magnificent, special woman. It's a feeling I want to push away. Makes me feel good ... and as if I'm going mad. (Prasad 1997, 00:54:14-36)

As Lígia Costa notes of Sandra, “[s]een through Parvez's eyes, there is no evil in her, in spite of her way of life [as Bettina]" (Costa 2008, p. 133). Invoking once again an ethics of goodness, Parvez's words echo the metaphorical association of love and madness so often found in Sufi poetry. ${ }^{80}$ In response, Sandra shakes Parvez's head firmly by the hair, as if to awaken him, and asks if Minoo does the same. Parvez blurts out, "She is too bloody ugly" (Prasad 1997, 00:58:08). Though a clumsy, even cruel condemnation of Minoo, it is nonetheless an honest admission that Parvez no longer cares for his wife in the way he once did and does now for Sandra. She responds with a comforting look and a reciprocal declaration of affection:

I lie in bed with the music on ... when I think of you. I get a warm feeling in my stomach ... and I have to close me [sic] eyes. (Prasad 1997, 00:58:35-46)

Again, the trope of music conveys a sense of harmony. A love scene immediately follows.

First, close-ups on the faces of the couple capture tender caresses and soft silent kisses (Prasad 1997, 00:58:52-59:32). An ecstatic moan from Parvez breaks the diegetic silence. Darkening rose tones pour over the couple, who disappear in a flood of vivid red light which completely fills the screen. Withdrawn to an omniscient position above Sandra's bed, the camera reintroduces the couple, fully naked in a seamless spooning embrace and bathed in the red light, which recalls the red gloves and red rose associated with Sandra earlier in the film and more broadly with "mystical gnosis" and "the wine of divine love" in Sufi writing (Prasad 1997, 00:59:34-59:40; p. 107; Schimmel 1975, pp. 35, 275). ${ }^{81}$ Throughout this sequence, non-diegetic South Asian jazz fusion complements and accentuates the harmony of the moment. Subtly building and gently subsiding in complexity, this musical accompaniment remains restrained in intensity, reflecting the way in which the camera understates the lovemaking between Parvez and Sandra, their naked embrace finally suggesting Edenic innocence, a far cry from the explicit sexuality so commonly indulged in contemporary film (Prasad 1997, 00:59:40-52). ${ }^{82}$ As Seyyed Hossein Nasr writes: "From the Sufi point of view, the urge for sexual union ... is in reality the search of the soul for union with God, especially when human union is combined with love" (Nasr 2007, p. 65).

80 Of Sufi verse from the early mystics to Rumi, for example, Mahmood Jamal writes: "The idea is to celebrate love, which breaks the chains of earthly existence and disconnects us from worldly gain or loss; the lover is lost in this world and discovers his true essence in the 'madness' of love" (Jamal 2009, p. 10). More broadly, Werbner observes that "[s]uch standard themes as madness, intoxication and dreams, and the use of stock Sufi imagery, intoxicating wine, the seal of the heart, stars, narcissi and overflowing rivers, all convey the poet's love and desolation" (Werbner 2017, p. 173).

81 Henry Corbin also refers to "the red light that is the dominant note in the visions of Ruzbehan [Baqli]: 'One night I saw something enveloping the Heavens. It was a sparkling red light. I asked: What is that? He told me: It is the cloak of Magnificence'" (Corbin 1978, p. 153, n. 86; italics added). Similarly, Parvez and Sandra are enveloped within a cloak of red light.

82 The title of the accompaniment, "Making Music", puns upon the couple's lovemaking, and in so doing, also echoes the metaphorical association of love and music so dear to a number of Sufi poets. Originally composed by Hariprasad Chaurasia (b. 1938) and Ustad Zakir Hussain (b. 1951), the music features tabla, bansuri, guitar, and sitar. For a recent performance, see Wahh (2010). Intermittently interspersed, excerpts from "Making Music" effectively serve as the theme music for My Son the Fanatic. Discussing "Parvez's two identities" as at once Pakistani and British, Mortensen notes of the soundtrack of My Son the Fanatic that "[t]he nondiegetic music is rooted in the East and represents his origins and his community, and the diegetic music is jazz, representing the Western world that he lives in now" (Mortensen 2005, p. 33). Such a stark opposition, though, fails to account for the nature of "Making Music" as South Asian jazz fusion. 
After the love scene, successive sequences highlight the extent to which Parvez is alienated from his own world, yet increasingly uncomfortable in the world in which 'Bettina' works with Schitz. While other taxi drivers taunt Parvez about his "girl-friend ... Bettina" (Prasad 1997, 01:02:06), Schitz engages him to arrange an extravagant party at the disused cotton mill the German businessman intends to redevelop as a shopping mall. In the taxi on the way to the event, 'Bettina's colleagues suggest that their relationship is "serious" because she refuses to talk about it, but "smiles a little bit" when she mentions him (Prasad 1997, 01:02:51-03:02). At the party, Parvez serves drinks but looks decidedly uneasy with the decadent debauchery he has helped to facilitate. While several sex-workers cavort provocatively in various states of undress, however, Sandra remains modestly covered in a long winter coat. Though seemingly partnered with Schitz, she notices Parvez's discomfort, leans over to him and silently mouths, "I love you" (Prasad 1997, 01:05:02). After the party, she acts upon this declaration by abandoning Schitz and leaving with Parvez (Prasad 1997, 01:05:52). Sandra's commitment forces Parvez to make a decision. Contrasting bedroom scenes capture his dilemma. In the first scene, rose tones once more tint the screen. Parvez is dressing and Sandra tells him, "I love you looking after me" (Prasad 1997, 01:06:25). She begs him to stay longer but he insists on going home. The camera cuts to the marital bedroom in the Aziz home. Parvez gives Minoo the "generous tip" he has earned from Schitz and, in a gesture at once affectionate and guilt-ridden, offers to take her to see the ruin Sandra showed him. "It's the first time you've asked me to go out and I'm gonna be too busy ... [1]ooking after some things", she replies (Prasad 1997, 01:08:01-09). We learn in the next scene that "some things" involve work in the kitchen with other women in support of the maulvi and his acolytes as they prepare for their campaign of moral reform. It is too late to save the marriage; Minoo already finds greater gratification in conservative Deobandi certainties.

Yet the sequences dramatizing Parvez's blossoming love for Sandra map not only the end of his marriage to Minoo, but more significantly, his gradual transformation into the sort of "good" man intended by the Sufi principle of ihsān. Interactions with other characters reflect this measured metamorphosis, at first with a touch of irony, then more overtly. Interrupted as he and his colleagues study the Qur'an, for example, Farid equivocates about joining his father for dinner at Fizzy's restaurant, but it is Parvez who invokes scripture. Well aware of the irony, he asks: "Isn't it written that you will respect your father?" (Prasad 1997, 00:38:16). Similarly, at that fateful meal in the restaurant Parvez grants Farid's request that the maulvi stay at their home: "Our house is open", he tells his son (Prasad 1997, 00:41:53). In due course, in a doubly ironic development, the "open" Aziz house serves as headquarters for the Deobandi maulvi's campaign of moral reform, in the manner of a traditional Sufi khangah. As the relationship between Parvez and Sandra develops, however, the irony dissipates. In contrast to the maulvi, for example, Parvez insists that Minoo join the men at the meal-table. "I won't eat without you", he protests, clearly upset that his wife remains in the kitchen, a revert to discriminatory Deobandi teaching on gender segregation (Prasad 1997, 01:01:15). Conversely, Parvez scrupulously performs the host's duties in the spirit of generosity prescribed in Sufi tradition. Like a humble servant attending his employer, he asks the maulvi, who is seated at the dining table watching television, "Can I get you something?" (Prasad 1997, 00:50:01). ${ }^{83}$

Elsewhere, finally, Parvez warns Farid of the dangers of the cleric's evangelical agenda: "He will stir up the pots [sic]. You don't know what these religious people are likeimposing mad ideas" (Prasad 1997, 00:48:13-15). Learning that these "mad ideas" have led

83 These words capture the spirit of al-Bukhari's hadith on the duties of the Muslim host: "[A] guest is to be entertained with food for three days", he writes, "and whatever is offered beyond that, is regarded as something given in charity" (Al-Bukhari 1996, p. 6135). 
to the beating of a teenaged sex-worker, Parvez apologizes to her colleagues for Farid's intolerant and intolerable behaviour (Prasad 1997, 01:03:14-32). Most tellingly, having dragged his son home from the riot, Parvez condemns Wahhabi and Salafi influences upon the Deobandi maslak in a theological judgment upon Farid's violent radicalism: "I won't stand for the extremity of anti-democratic and anti-Jewish rubbish! ... There is nothing of God in spitting on a woman's face. This cannot be the way for us to take!" (Prasad 1997, 01:16:33-41). When Farid storms from the house, Parvez dutifully pursues his son in the taxi (Prasad 1997, 01:18:38). As Farid turns into the side-street to meet his fellow zealots, Parvez calls out to him from the taxi: "Remember two things. There are many ways of being a good man. And I will be at home. Will you come and see me?" (Prasad 1997, 01:19:44-56). Not only has love clarified Parvez's ethical and theological vision to the disadvantage of the Deobandi maslak distorted by the violence of Farid and his cohort, he now sees the postcolonial United Kingdom as "home", too, and with unconditional parental affection hopes for his son's return, despite Farid's unfilial behaviour.

\section{Conclusions}

From the album Second Light (1995) by the English band Dreadzone, the non-diegetic song "Little Britain" accompanies the opening scenes of My Son the Fanatic:

In this green and pleasant land

We have a treat you understand

In the mountains of the mind

There is a spirit you will find

Just like an angel from above

We turn to the little words of love

Ancient cross and Zion star

Eastern wings and praise to Jah

This is our land

This is your land

This is our inheritance

[To lead you on a merry dance] (Prasad 1997, 00:00:15-03:32)

The music mixes the Caribbean genres of dub and reggae with British electronica, while the lyrics introduce postcolonial themes couched in religious tropes. On the one hand, the words "green and pleasant land", which close the patriotic Anglican hymn 
"Jerusalem", conjure traditionalist English sentiments. ${ }^{84}$ In this sense, from the migrant point of view, England is "your land." On the other hand, the Rastafarian symbols "Ancient cross", "Zion", "Eastern wings", and "Jah" testify to the presence of migrants in "this green and pleasant land". In this respect, from the migrant point of view, England is "our land." Such competing perspectives risk hostility. "Just like an angel from above", however, "little words of love" offer to dissolve tensions arising from these ostensibly opposed claims to the land in the shared vision of "our inheritance". 85

Drawing upon Rastafarian religious tropes to envision the postcolonial United Kingdom as a shared inheritance animated by "little words of love", "Little Britain" invites us to identify religious iconography at play in My Son the Fanatic and to explore the sort of life in England's "green and pleasant land" that the film projects for immigrant communities associated with it. For Farid, a second-generation Pakistani Muslim justifiably resentful of entrenched British racism, reversion to revivalist Deobandi teachings and the missionary mandate of the Tablighi Jama'at offers a viable option: reject western popular culture; seek a Muslim bride; wear traditional Islamic clothes; learn to pray in Arabic; look to the Qur'an as the authoritative guide for everyday life and study it in a group of like-minded enthusiasts; preach the faith to "thirsty" Muslims in prison; secure the tutelage of a recog-

84 The phrase "green and pleasant land" appears in the poem, "And Did Those Feet in Ancient Time", by visionary English Romantic writer William Blake (1757-1827). Blake's poem speculates about the presence of Jesus Christ in England:

And did those feet in ancient time,

Walk upon England's mountains green:

And was the holy Lamb of God,

On England's pleasant pastures seen!

And did the Countenance Divine,

Shine forth upon our clouded hills?

And was Jerusalem builded here,

Among these dark Satanic Mills?

Bring me my Bow of burning gold:

Bring me my Arrows of desire:

Bring me my Spear: O clouds unfold:

Bring me my Chariot of fire!

I will not cease from Mental Fight,

Nor shall my Sword sleep in my hand:

Till we have built Jerusalem,

In England's green \& pleasant Land. (Blake [1808] 1982, pp. 95-96)

For Blake, "Jerusalem" represents humanitarian resistance to the "dark Satanic Mills" of encroaching industrialization. In 1916, Sir Hubert Parry (1848-1918) scored the poem as the Anglican hymn "Jerusalem." Traditionalist Britons will be more familiar with the 1922 orchestral version of Sir Edward Elgar (1837-1948), which plays at public events ranging from football matches to the "Last Night of the Proms" at London's Royal Albert Hall. On such occasions, "Jerusalem" rivals "God Save the Queen" for its nationalist sentiments.

The lyrics of "Little Britain" continue in a spirit of inclusive optimism:

In the beginning there was light

Shining path and journeys bright

When the nations pray as one

Then will the races all be won

In this green and pleasant land

We have a dream to understand

Open paradises gate

Dance on the land and celebrate

Say no matter what your color

Your race or your culture

This is our inheritance

To lead you on a merry dance (Dreadzone 1995)

Note the way tropes of light, journeying, prayer, dreaming, paradise and dance frame the postcolonial vision of multicultural harmony expressed in the skillful puns of the line, "Then will the races all be won" (italics added). 
nized spiritual authority; and help to establish a khanqah as headquarters for a campaign of moral reform. Elders at a local mosque perceive a degree of self-righteousness in the young men who propagate this interpretation of the faith, yet they cannot help but admire their forthrightness. Farid's mother, Minoo, supports her son in his new-found piety, too, and herself willingly reverts to the sort of gendered behaviour such conservative Muslim doctrine demands.

As we have seen, the Punjabi maulvi articulates in more formal, if doctrinaire terms the theology of dawa inspiring the proselytizing work of the Deobandis and the Tablighi Jama'at: "But right conduct is possible, provided that the preacher advises and warns that in the military industrial state, that the greatness of God's guidance is essential in guaranteeing repentance" (Prasad 1997, 1:09:15-1:10:03). Influenced by Salafi and Wahhabi views from the 1990s on, however, "the isolationist, anti-Western rhetoric preached by Deobandi ulema, seminaries and mosques [likely] contributes to the growing willingness of young British Muslims to commit violent acts" (Westrop 2016, p. 466). ${ }^{86}$ It is true that filial affection prompts Farid to rescue the barefooted Parvez from the cold and to drive him home inebriated from Fizzy's restaurant. At the same time, though, he goes "too far", as his father foresees, as he brutally assaults 'Bettina' and fiercely condemns Parvez as "pimp" and "dirty man" (Prasad 1997, 00:43:30). Neither is the cleric without his faults. He delights in misogynistic cartoons playing on a television he is not supposed to watch, and he abuses his privileged status as a guest in the Aziz home. Parvez himself points out the maulvi's hypocrisy to Farid: "Your great long-beard friend wants to stay in this immoral country! Knowing of my Fingerhut connections, he wants me to help him with the immigration!" (Prasad 1997, 1:10:36-45). More importantly, the maulvi proves powerless to prevent his acolytes from beating a teenaged sex-worker, still less the later assaults on her older colleagues and the fire-bombing of their brothel when the crusading group's moralizing campaign escalates into a riot.

If, then, Deobandi doctrine and Tablighi Jama'at dawa appeal to the moral enthusiasm of disillusioned and disenfranchised young Pakistani men in the postcolonial United Kingdom, such revivalist movements may also provoke the sort of militant interpretation of Islam that justifies overtly vicious means to achieve ostensibly virtuous ends. In this respect, as Wright has observed, commentators lament that My Son the Fanatic seems to offer "no sustained Muslim critique of militancy" and "participates in the elision of 'Islam' into 'fundamentalism' in contemporary popular Western discourse" (Wright 2007b, p. 117). Casting them as "the least assimilable and the most dangerous of minority groups", she continues, this interpretation of the film identifies "young Muslims in the West" like Farid and his cohort with "events like the Salman Affair (1989), and ... the terror attacks on the USA on 11 September 2001 and in London on 7 July 2005" (Wright 2007b, p. 117). Yet several factors mitigate such retrospective readings of My Son the Fanatic as a "documentary or quasi-documentary" exposé of the role of revivalist Muslim movements in the radicalization of contemporary Muslim youth (Wright 2007a, p. 30). Farid and Minoo are right to judge Parvez an adulterer who has facilitated the hedonistic excesses of the German businessman Schitz. ${ }^{87}$ "Filthy, selfish man", Minoo declares, echoing her son's words and identifying her husband with "the soulless consumerism Farid terms 'empty accountancy'" (Prasad 1997, 01:19:04; Wright 2007a, p. 34). In another vein, the Punjabi maulvi issues an express prohibition against violence and seeks legal means to further his missionary calling.

More importantly, however, My Son the Fanatic demands that we view the Deobandi convictions of the Punjabi cleric and his followers, including Farid and Minoo, from

86 It should be noted that Wahhabi and Salafi views do not of necessity lead to violence. Of the "British experience" of "Islamic radicalism and multicultural politics", for example, Abbas notes: "'Reformist' Salafis believe in individual and social change through spreading the message widely and its formal education, while some 'jihadi-Salafists' believe in the necessity of violence ('physical jihad') in achieving societal and religious goals" (Abbas 2011, p. 24).

87 In this latter respect, Mortensen argues that the relationship between Parvez and Schitz "resembles that of a colonial master and a native servant" (Mortensen 2005, p. 32). 
Parvez's perspective, that is, through the lens of the Sufi folk traditions that shaped his upbringing. That is not to say, it must be stressed, that Parvez consciously espouses or even entertains conventional Sufi aspirations; clearly, he does not. From a Sufi standpoint, his moral failures range from the habitual consumption of alcohol to the deception of Minoo and the assault upon Farid. ${ }^{88}$ As Wright remarks, "[f]rom a religion and film perspective ... My Son's 'message' is overwhelmingly secular" (Wright 2007b, p. 115). In this respect, though, what Wright calls the "the visual organisation" of the film develops the character of Parvez in terms of tropes and themes transposed from the Sufi imaginary to the secular world of northern England's post-industrial fictional 'Bradford': tolerance for members of other communities of faith; taxi-driving recalling the motifs of journeyer and guide; fondness for the soulful music of jazz and rhythm-and-blues aping Sufi adaptations of South Asian folk music; the lush greens and purifying waters of the English countryside recalling poetic accounts of Islamic paradise; the mysterious nature of an angelic personality, at once fallen 'Bettina' and redemptive Sandra; serving as beneficent host to those in need of shelter and, albeit unintentionally, enabling the dissemination of the faith; the red rose of the beloved and the red gloves and rose-toned illumination of love's embrace; and most tellingly, the gradual realization of a philosophy of life embodied and expressed in the Islamic virtue of ihsān, that is, the cultivation of the beautiful and good (Wright 2007b, p. 118). ${ }^{89}$

In three sequences, the closing action of My Son the Fanatic gathers these tropes and themes into a harmonious conclusion, as Parvez faces the new realities confronting him. The language of goodness and love pervades these sequences. Either side of Farid's departure, scenes in the home determine the future of the Aziz marriage, the first in the living-room. Readable as a pun on "for good", Parvez pleads with Minoo: "Just tell me, what can I do to make you happy? If you just tell me once, then I'll know for good" (Prasad 1997, 01:18:47-50). He admits a "friendship" with Sandra (Prasad 1997, 01:19:04). "Friendship is good, Minoo", he continues, explaining that "it can be found in the funniest of places", in an apparent reference to the arched ruin in the paradisal woodland where first he began to awaken to the magical allure of Sandra masquerading as the sex-worker 'Bettina' (Prasad 1997, 01:19:09-14). Minoo rightly condemns him for his thoughtless ingratitude: "All this time I stayed here to serve you", she laments, "What a waste!" (Prasad 1997, 01:19:15-25). After Parvez returns from his futile pursuit of Farid, the scene shifts to the marital bedroom, where Minoo is packing a suitcase. She intends to return to Pakistan: "I'll see everyone who loves me" (Prasad 1997, 01:20:25). While Parvez insists that he has "done nothing wrong", Minoo disagrees: "Yes. One unforgiveable thing. Put self before family" (Prasad 1997, 01:20:31-41). The accusation strikes home. Finally, sincerely invoking the divinity for the second time in the film, Parvez confesses: "O, God, yes. The first time, but not the last" (Prasad 1997, 01:20:44-49). In turn, this confession now leads him to put family before self. He does not intend to stay in the United Kingdom because of Sandra, but because Farid might "one day tire of his moral exertions" and "need" him (Prasad 1997, 01:20:33-41). But questions remain. Will Minoo return "home" to the United Kingdom (Prasad 1997, 01:21:13)? Does Parvez want her to? Will he go to Pakistan to bring Minoo back? "It is too late now for us to be parted for good", Parvez suggests, in words once more readable as a pun on "for good" (Prasad 1997, 01:21:35). Tellingly, it falls to Minoo to state the truth he has been avoiding: "No, it's not. I can tell you have lost your feeling for me" (Prasad 1997, 01:21:40-44). Ironically, Minoo, the conservative Deobandi revert, speaks the words that implicitly portend the "good" for them both that will follow from their parting.

For Parvez, of course, this "good" has to do with his love for Sandra. Appropriately, the penultimate sequence of My Son the Fanatic returns us straightaway to the evergreen

88 Trevor Douglas Smith describes Parvez as "a domineering, adulterous, and violent man" (Smith 2004, p. 91).

89 Though analysis here focuses on the ethics of goodness, it is worth reminding that "My Son the Fanatic" describes Parvez as wishing to awaken Farid to "the beauty of living" (Kureishi 1997, p. 129). 
woodland we visited near the opening of the film. This time, however, we are not moving among hills; the camera remains fixed on the flat. Dressed casually in jeans and a colourful sweater, Sandra stands in the middle distance at the centre of the frame, nonchalantly smoking a cigarette. Again, a songbird chortles somewhere in the trees. In a deep-focus shot, Parvez enters the foreground from the right, arms crossed, head bowed in reflection. With a self-deprecating chuckle he sums up his situation in language that echoes the paradoxical sense of existential mystery at the heart of Sufi thinking: "I have managed to destroy everything. I've never felt worse ... or better" (Prasad 1997, 01:22:03-09). As the camera slowly zooms in to a same-frame two-shot of their faces in intimate closeup, she discards the cigarette and assumes a more serious tone. Perhaps they should leave for a few weeks in India, she suggests, where he might show her "the good places" (Prasad 1997, 01:22:29). At once capturing the sense of rebirth implicit in Parvez's paradoxical confession and reversing the roles associated with their earlier visit to the arched ruin high among the fir trees, Sandra coaxes Parvez to think of their future together as a new beginning: "Come way. It's a chance. Otherwise what will we do but the same thing every day" (Prasad 1997, 01:22:45-50). When he challenges her for proposing "such ideas", she replies: "Good. That's good" (Prasad 1997, 01:22:56-23:00). Asked what she wants, Sandra pauses, head lowered thoughtfully for a moment, then affirms her complete commitment to a future with Parvez: "More than I've ever had before. Your face. Your hands. You. All of you. You", and finally, as he buries his head in her shoulder, she embraces him with kisses: "I want you" (Prasad 1997, 01:23:12-38). Peppered with suggestions of the "good" and sealed with emphatic devotion, Sandra's words reiterate the language of $i$ hsann informing Parvez's own philosophy of life and urge him to act upon it.

My Son the Fanatic does not transport Parvez and Sandra to India, however. Their future remains unseen and unspoken. Instead, the film's final sequence comprises an intermedial interplay between the celebration of love and the symbolism of light-respectively, as we have seen, a classic Sufi theme and a classic Sufi trope. Positioned inside the house, the camera focuses on the front door. The Aziz home is deserted and in shadowy darkness. Farid, Minoo, and the Punjabi maulvi and his acolytes have all left. The front door opens and Parvez enters. A reverse shot sees him walk through the hall on the first floor, his path vaguely illuminated by outside light filtered through the kitchen window at the rear of the house. The camera does not move. In the gloomy middle distance, Parvez opens the door to the basement and descends the stairs. We hear the flick of a switch and through the door light reflected upstairs from Parvez's 'man-cave' brightens the hall. A record-player whirls into life, the credits begin to roll over the mise-en-scène and the first stanza of the rhythm-and-blues classic, "Please Send Me Someone to Love", by African-American Percy Mayfield (1920-1984), fills the air:

Heaven, please send to all mankind

Understandin' and peace of mind

But if it's not askin' too much

Please send me someone to love

Someone to love. (Prasad 1997, 01:24:30-54)

Addressed to "Heaven", like a secular hymn, this humble plaint for "peace" and "love", at once universal and personal in its appeal, accompanies Parvez as he reappears from the basement, a glass and bottle of whisky in hand. The ballad continues as Parvez rounds the basement door into the kitchen, passes out of sight into the dining-room, reenters the hall from the living-room in the left foreground of the frame, glass and bottle now in one hand, jacket in the other, turning on lights as he goes and illuminating the entire first floor of the house. He hangs his jacket on the newel post at the foot of the stairs that lead up to the second floor.

The stairs and the second floor of the house are in darkness. Energized, Parvez runs upstairs with glass and whisky. Mayfield begins the second stanza: 
Show all the world how to get along

Peace will enter when hate is gone.

But if it's not askin' too much

Please send me someone to love

Please send me someone to love. (Prasad 1997, 01:24:58-25:26)

Still addressed to "Heaven", the language of peace's entry and hate's departure reflects recent comings and goings at the Aziz home, recasting it as a microcosm of hope for "the world." As the music proceeds, Parvez rounds the newel at the top of the stairs. He disappears from view, but light floods the staircase and the second floor, as out of sight Pavez flicks more switches. He returns to view at the top of the stairs, leans against the wall and surveys the work of illumination with a look first of satisfaction, then of reflection. He sits down on the top stair, pours a glass of whisky, sits against the wall, then lies back on the landing, his face out of sight of the camera. As he does so, the melody and meaning of "Please Send Me Someone to Love" turn more reflective, too:

I lay awake nights and ponder world troubles

And my answer is always the same

That unless man put an end to this damnable sin

Hate will put the world in a flame, what a shame

Just because I'm in misery

I don't beg for no sympathy

But if it's not asking too much

Just send me someone to love. (Prasad 1997, 01:25:40-26:55)

In a house full of light, Mayfield's lyrics once again explicitly invoke "love" as the answer to an apocalyptic vision of a "world in a flame" and the sort of personal "misery" that "damnable sin" and "hate" will regrettably, but inevitably generate. At the same time, stationary and stable throughout this closing sequence, the omniscient camera-our eyes-pans a little left and right, zooms a little in and out, and tilts a little up and down, following Parvez or anticipating his movements. If the lyrics express Parvez's situation, they also reflect our extradiegetic perspective, for as we have seen, My Son the Fanatic encourages us to see the world through the eyes of Parvez. As credits and mise-en-scène fade to black, the music draws to a close. The conservative teachings of the Deobandi maslak and Tablighi Jama'at dawa may indicate a stairway to heaven, but in their pursuit of this truth, the violent extremism of Farid and his cohort perverts such an understanding of the faith. By contrast, the transposition of tropes and themes from the Sufi imaginary to the secular world of the postcolonial United Kingdom leaves Parvez in love and in light, halfway up the stairs to heaven, as he begins to rediscover what it means to be a good 
man. ${ }^{90}$ Put otherwise, My Son the Fanatic suggests conditions of possibility for authentic Muslim living in a non-Muslim social and cultural environment, a sacralized secularity in the making reminiscent of the words of Conservative British peer, Sayeeda Warsi: "Islam is not ethnically, geographically or culturally specific, it is indeed 'a river which takes the colour of the bed over which it flows'"' (Warsi 2017, p. 48).

Funding: This research received no external funding.

Conflicts of Interest: The author declares no conflict of interest.

\section{References}

Abbas, Tahir. 2011. Islamic Radicalism and Multicultural Politics: The British Experience. London: Routledge.

Ahmed, Leila. 1992. Women and Gender in Islam: Historical Roots of a Modern Debate. New Haven: Yale University Press.

Al-Bukhari, Muhammad bin Ismail. 1996. [ca. 846]. Book of Good Manners and Form [Al-Adab]. In Translation of the Meanings of Sahih al-Bukhari. Translated by Muhammad Muhsin Khan. Ankara: Hilal Yayinlari, vol. 9. Available online: https://sunnah.com/ bukhari/78 (accessed on 8 September 2020).

Alexiev, Alex. 2005. Tablighi Jamaat: Jihad's Stealthy Legions. Middle East Quarterly 12: 3-11.

Al-Qurtubi, Abu 'Abdullah. 2003. Tafsir al-Qurtubi: Classical Commentary of the Holy Qur'an. Translated by Aisha Bewley. London: Dar al-Taqwa, vol. 1.

Arun-Qayyum, Sham. 2016. People, Not Only Societies, Are Multicultural: An Interdisciplinary Study Examining How Muslims in Britain Are Negotiating Overlapping (Legal) Norms, Identities and Traditions. Unpublished. Ph.D. dissertation, University of London, London, UK. Available online: https:/ / eprints.soas.ac.uk/23811/1/Arun-Qayyum_4331.pdf (accessed on 16 July 2020).

Ayoub, Mahmoud M. 2004. Islam: Faith and History. Oxford: Oneworld.

Bhar, Aparna. 2014. Representations of British South Asian Diasporic Identities in Contemporary British Audio-Visual Media. Unpublished Ph.D. dissertation, Universität Trier Fachbereich II Anglistik, Trier, Germany. Available online: https:/ / ubt.opus. hbz-nrw.de/opus45-ubtr/frontdoor/deliver/index/docId/653/file/PhD_Full_Doc_for_Lib.pdf (accessed on 11 July 2020).

Birt, Jonathan, and Philip Lewis. 2011. The Pattern of Islamic Reform in Britain: The Deobandis between Intra-Muslim Sectarianism and Engagement with Wider Society. In Producing Islamic Knowledge in Western Europe. Edited by Martin van Bruinessen and Stefano Allievi. London: Routledge, pp. 91-119.

Black, Carolyn. 2003. Pakistan: The Culture. New York: Crabtree.

Blake, William. 1982. And Did Those Feet in Ancient Time. In Complete Poetry and Prose of William Blake. Edited by David V. Erdman. Commentary by Harold Bloom. New York: Anchor Books, pp. 95-6. First published 1808.

Bloom, Jonathan M., and Sheila S. Blair. 2002. Islam: A Thousand Years of Faith and Power. New Haven: Yale University Press.

Bowen, John R. 2016. On British Islam: Religion, Law, and Everyday Practice in Shari'a Councils. Princeton: Princeton University Press.

Böwering, Gerhard. 2001. The Light Verse: Qurānic Text and Sūfī Interpretation. Oriens 36: 113-44. [CrossRef]

Brown, Percy. 2004. Indian Architecture: Islamic Period, 1192-1857. New Delhi: Prakash Books.

90 The figure "stairway to heaven" echoes Nasr's discussion of "the gradation and hierarchy of love" in Sufi tradition, which begins with "love of the ego" and moves through "the love of others" and "love for the sacred realities" to "the love for God" (Nasr 2007, p. 63). "Conjugal and romantic love", he continues, "is the testing ground for the growth of the soul emotionally and spiritually, and it is related directly to the love and ultimate union between the soul and the Spirit" (Nasr 2007, p. 64). In this sense, love lies at the heart of a Muslim ethics of goodness. Without love, Farid's quest is misguided; in love, Parvez is on the right track. Mahmoud M. Ayoub explains in the context of the tradition's core concepts, islām [submission to God], imān [faith] and ihsān [goodness]:

[N]ot every Muslim is a man or woman of faith $\left(m u^{\prime} \min\right.$ [from ìmān]), but every person of faith is a muslim [from isläm]. Furthermore, a Muslim who believes in all the principles of Islam may not necessarily be a righteous person, a doer of good (muhsin [from ihsān]), but a truly good and righteous person is both a muslim and a true person of faith. (Ayoub 2004, p. 54)

In My Son the Fanatic, that is to say, Parvez is clearly not a person of faith, like Farid, who is therefore a Muslim in that regard. But Farid is not a doer of good, and therefore not a righteous person. In pursuing an ethics of goodness, on the other hand, Parvez is a Muslim, and therefore a person of faith. In this respect, Smith correctly describes Parvez as "not a religious man", that is, not a $m u^{\prime}$ 'min, but notes that he "still tries to be good and see it in others" (Smith 2004, p. 91). He concludes that therefore he is "a secular humanist" (Smith 2004, p. 91). Such a view, however, does not take account of the way the film draws upon Sufi tropes and themes to develop the character of Parvez as a muhsin-a doer of good-and thus, at least in potentia, "both a muslim and a true person of faith" (Smith 2004, p. 91). In a related way, Kureishi himself captures the apparent paradox at work here:

I have often been asked how it's possible for someone like me to carry two quite different world-views within, of Islam and the West; not, of course, that I do. Once my uncle said to me with some suspicion: "You're not a Christian, are you?" "No", I said, "I'm an atheist." "So am I", he replied. "But I am still Muslim." "A Muslim atheist?" I said, "it sounds odd." He said, "Not as odd as being nothing, an unbeliever". (Kureishi 2005, pp. 86-87)

Similarly, Parvez's secular leanings do not mean that he is not Muslim, for he believes in "good." In broader terms, to use Lumbard's words: "Law and creed, which could be said to correspond to islām and imān respectively, are an integral component of any Islamic society, but without the vivifying presence of a full-fledged ihsāni tradition, they become opaque and are soon bereft of that light by which God guides" (Lumbard 2004, p. 67). 
Bruce, Steve. 2008. Fundamentalism, 2nd ed. Cambridge: Polity Press.

Chittick, William C. 1995. Sufism: Sufi Thought and Practice. In The Oxford Encyclopedia of the Modern Muslim World. Edited by John L. Esposito. Oxford: Oxford University Press, pp. 102-9.

Cook, Michael A., ed. 2010. New Cambridge History of Islam. Cambridge: Cambridge University Press, vol. 6.

Copier, Laura. 2005. Radicalism Begins at Home: Fundamentalism and the Family in My Son the Fanatic. In Shooting the Family: Transnational Media and Intercultural Value. Edited by Patricia Pisters and Wim Staat. Amsterdam: Amsterdam University Press, pp. 89-101.

Corbin, Henry. 1978. The Man of Light in Iranian Sufism. Translated by Nancy Pearson. Boulder: Shambhala.

Costa, Lígia. 2008. Reading a Book, Reading a Film: A Portrait of Youth in 'My Son the Fanatic'. Anglo-Saxonica 26: 125-35.

Draper, Peter. 2005. Islam and the West: The Early Use of the Pointed Arch Revisited. Architectural History 4: 1-20. [CrossRef]

Dreadzone. 1995. Little Britain. In Second Light. London: Virgin Records.

Ernst, Carl W., and Bruce B. Lawrence. 2002. Sufi Martyrs of Love: The Chishti Order in South Asia and Beyond. New York: Palgrave Macmillan.

Esposito, John L., ed. 2003. Oxford Dictionary of Islam. Oxford: Oxford University Press.

Fast, Susan. 2001. In the Houses of the Holy: Led Zeppelin and the Power of Rock Music. Oxford: Oxford University Press.

Gaborieau, Marc. 2000. The Transformation of Tablîghî Jamâ'at into a Transnational Movement. In Travellers in Faith: Studies of the Tablîghî Jamâ'at as a Transnational Islamic Movement for Faith Renewal. Edited by Muhammad Khalid Masud. Leiden: E. J. Brill, pp. 121-38.

Gaborieau, Marc. 2006. What Is Left of Sufism in Tablîghî Jamâ'at? Archives de Sciences Sociales des Religions 135: 53-72. [CrossRef]

Gellner, Ernest. 1992. Postmodernism, Reason and Religion. London: Routledge.

Ghabin, Ahmad Y. 1998. The Quranic Verses as a Source for Legitimacy or Illegitimacy of the Arts in Islam. Der Islam 75: $193-225$. [CrossRef]

Gugler, Thomas K. 2010. The New Religiosity of Tablīghī Jamāat and Dawat-e Islāmī and the Transformation of Islam in Europe. Anthropos 105: 121-36. [CrossRef]

Gugler, Thomas K. 2016. Islamization and Barelvis in Pakistan. In Faith-Based Violence and Deobandi Militancy in Pakistan. Edited by Jawad Syed, Edwina Pio, Tahir Kamran and Abbas Zaidi. London: Palgrave Macmillan, pp. 369-97.

Gull, Ayyaz. 2018. Hearts to Seek God: Sama and Happiness at Chishti Sufi Shrines in Colonial Punjab. The Historian 16: 47-72.

Haq, M. Anwarul. 1972. The Faith Movement of Mawlana Muhammad Ilyas. London: Allen \& Unwin.

Harris, Diana. 2002. A Report on the Situation regarding Teaching Music to Muslims in an Inner-city School. British Journal of Music Education 19: 49-60. [CrossRef]

Hashmi, Arshi Saleem. 2016. Historical Roots of the Deobandi Version of Jihadism and Its Implications for Violence in Today's Pakistan. In Faith-Based Violence and Deobandi Militancy in Pakistan. Edited by Jawad Syed, Edwina Pio, Tahir Kamran and Abbas Zaidi. London: Palgrave Macmillan, pp. 132-61.

Hassan, Riffat. 2017. Introduction. In Muhammad Iqbal: Essays on the Reconstruction of Modern Muslim Thought. Edited by Chad Hillier and Basit Koshul. Edinburgh: Edinburgh University Press, pp. 1-11.

Hassanali, Muhammed. 2010. Sufi Influence on Pakistani Politics and Culture. Pakistaniaat: A Journal of Pakistan Studies 2: $23-45$.

Hermansen, Marcia. 2008. A Twentieth Century Indian Sufi Views Hinduism: The Case of Khwaja Hasan Nizami (1879-1955). Comparative Islamic Studies 4: 157-79. [CrossRef]

Hill, Joseph. 2019. Sufism between Past and Modernity. In Handbook of Contemporary Islam and Muslim Lives. Edited by Mark R. Woodward and Ronald Lukens-Bull. Cham: Springer. Available online: https://link.springer.com/referenceworkentry/10.1007\%2F978-3-319-7 3653-2_9-1 (accessed on 20 September 2020).

Hoodbhoy, Pervez. 2016. Could Pakistan Have Remained Pluralistic? In Faith-Based Violence and Deobandi Militancy in Pakistan. Edited by Jawad Syed, Edwina Pio, Tahir Kamran and Abbas Zaidi. London: Palgrave Macmillan, pp. 35-64.

Horstmann, Alexander. 2009. Transnational Ideologies and Actors at the Level of Society in South and Southeast Asia. In Transnational Islam in South and Southeast Asia: Movements, Networks, and Conflict Dynamics. Edited by Peter Mandaville, Farish A. Noor, Alexander Horstmann, Dietrich Reetz, Ali Riaz, Animesh Roul, Noorhaidi Hasan, Ahmad Fauzi Abdul Hamid, Rommel C. Banlaoi and Joseph Chinyong Liow. Seattle: National Bureau of Asian Research, pp. 35-52.

Ingram, Brannon D. 2009. Sufis, Scholars and Scapegoats: Rashid Ahmad Gangohi (d. 1905) and the Deobandi Critique of Sufism. The Muslim World 99: 478-501. [CrossRef]

Ingram, Brannon D. 2018. Revival from Below: The Deoband Movement and Global Islam. Oakland: University of California Press.

Jackson, William Kesler. 2013. A Subcontinent's Sunni Schism: The Deobandi-Barelvi Rivalry and the Creation of Modern South Asia. Unpublished Ph.D. dissertation, Department of History, Syracuse University, Syracuse, NY, USA. Available online: https:/ / surface.syr.edu/hst_etd/102 (accessed on 1 August 2020).

Jamal, Mahmood, ed. 2009. Islamic Mystical Poetry: Sufi Verse from the Early Mystics to Rumi. London: Penguin.

Jawad, Haifaa, and Tansin Benn, eds. 2003. Muslim Women in the United Kingdom and beyond: Experiences and Images. Leiden, Boston: Brill.

Kamran, Tahir. 2016. The Genesis, Evolution and Impact of 'Deobandi' Islam on the Punjab: An Overview. In Faith-Based Violence and Deobandi Militancy in Pakistan. Edited by Jawad Syed, Edward Pio, Tahir Kamran and Abbas Zaidi. London: Palgrave Macmillan, pp. 65-92. 
Khan, Fareeha. 2009. Maulana Thanawi's Fatwa on the Limits of Parental Rights over Children. In Islam in South Asia in Practice. Edited by Barbara D. Metcalf. Princeton: Princeton University Press, pp. 305-16.

Khan, Arsalan. 2016. Islam and Pious Sociality: The Ethics of Hierarchy in the Tablighi Jamaat in Pakistan. Social Analysis 60: 96-113. [CrossRef]

King, John. 1997. The Tablighi Jamaat and the Deobandi Mosques in Britain. In Islam in Europe: The Politics of Religion and Community. Edited by Steven Vertovec and Ceri Peach. London: Palgrave Macmillan, pp. 129-46.

Knysh, Alexander. 2000. Islamic Mysticism: A Short History. Leiden: Brill.

Knysh, Alexander. 2017. Sufism: A New History of Islamic Mysticism. Princeton: Princeton University Press.

Kureishi, Hanif. 1997. My Son the Fanatic. In Love in a Blue Time. London: Faber and Faber, pp. 119-31.

Kureishi, Hanif. 2005. Sex and Secularity. In The Word and the Bomb. London: Faber and Faber, pp. 81-88.

Lapidus, Ira M. 1996. State and Religion in Islamic Societies. Past E Present 151: 3-27.

Lewis, Philip. 2002. Islamic Britain: Religion, Politics and Identity among British Muslims. Revised ed. London: I.B. Taurus. First published 1994.

Lewis, Dave. 1991. Led Zeppelin: A Celebration. London: Omnibus Press.

Lewis, Philip. 2004. New Social Roles and Changing Patterns of Authority amongst British 'Ulamâ. Archives de Sciences Sociales des Religions 49: 169-87.

Lumbard, Joseph E.B. 2004. The Decline of Knowledge and the Rise of Ideology in the Modern Islamic World. In Islam, Fundamentalism, and the Betrayal of Tradition, Revised and Expanded: Essays by Western Muslim Scholars. Edited by Joseph E.B. Lumbard. Bloomington: World Vision, pp. 39-77.

MacCabe, Colin, and Hanif Kureishi. 2003. Hanif Kureishi and London. AA Files 49: 40-49.

Majed, Hasan Saeed. 2015. Islamic Postcolonialism: Islam and Muslim Identities in Four Contemporary British Novels. Newcastle-upon-Tyne: Cambridge Scholars.

Metcalf, Barbara D. 1978. The Madrasa at Deoband: A Model for Religious Education in Modern India. Modern Asian Studies 12: 111-34. [CrossRef]

Metcalf, Barbara D. 1982. Islamic Revival in British India: Deoband 1860-1900. Princeton: Princeton University Press.

Metcalf, Barbara D. 1996. New Medinas: The Tablighi Jama'at in America and Europe. In Making Muslim Space in North America and Europe. Edited by Barbara D. Metcalf. Berkeley: University of California Press, pp. 110-27.

Metcalf, Barbara D. 1998. Women and Men in a Contemporary Pietist Movement: The Case of the Tablighi Jama'at. In Appropriating Gender: Women's Activism and Politicized Religion in South Asia. Edited by Amrita Basu and Patricia Jeffery. New York: Routledge, pp. 107-21.

Metcalf, Barbara D. 2002. 'Traditionalist' Islamic Activism: Deoband, the Tablighis, and Talibs. In ISIM Papers. Leiden: International Institute for the Study of Islam in the Modern World.

Modood, Tariq. 2005. Multicultural Politics: Racism, Ethnicity, and Muslims in Britain. Minneapolis: University of Minnesota Press.

Moj, Muhammad Tariq. 2015. The Deoband Madrassah Movement: Countercultural Trends and Tendencies. London: Anthem Press.

Mortensen, Trine Winter. 2005. The Empty Accountancy of Things: Reasons for Fundamentalism in Hanif Kureishi's and Udayan Prasad's My Son the Fanatic. pov: A Danish Journal of Film Studies 20: 31-40.

Mottahedeh, Roy P. 1985. The Mantle of the Prophet: Religion and Politics in Iran. New York: Simon and Schuster.

My Son the Fanatic. 1997. Internet Movie Database. Available online: https:/ /www.imdb.com/title/tt0119743/ (accessed on 10 April 2020).

Naeem, Fuad S. 2004. A Traditional Islamic Response to the Rise of Modernism. In Islam, Fundamentalism, and the Betrayal of Tradition, Revised and Expanded: Essays by Western Muslim Scholars. Edited by Joseph E.B. Lumbard. Bloomington: World Vision, pp. 79-116.

Nasr, Seyyed Hossein. 2007. The Garden of Truth: The Vision and Practice of Sufism, Islam's Mystical Tradition. New York: HarperOne.

Noor, Farish A. 2012. Islam on the Move: The The Tablighi Jama'at in Southeast Asia. Amsterdam: Amsterdam University Press.

Philippon, Alix. 2012. The 'Urs of the Patron Saint of Lahore: National Popular Festival and Sacred Union between the Pakistani State and Society? Social Compass 59: 289-97. [CrossRef]

Prasad, Udayan dir. 1997. My Son the Fanatic. Screenplay by Hanif Kureishi. Miramax.

Rababah, Hussien, and Yusuf Rababah. 2016. Rules and Ethics of Hospitality in Islam. Journal of Culture Society and Development 20: 44-56.

Rahman, Fazlur. 2009. Major Themes of the Qur'an, 2nd ed. Chicago: University of Chicago Press. First published 1980.

Rahman, Tariq. 2004. Denizens of Alien Worlds: A Survey of Students and Teachers at Pakistan's Urdu and English Language-medium Schools and Madrassas. Contemporary South Asia 13: 307-26. [CrossRef]

Rahman, Mohammed Mahbubur. 2015. Islamic Architecture and Arch. International Journal of Built Environment and Sustainability 2: 8-16. [CrossRef]

Reetz, Dietrich. 2004. Keeping Busy on the Path of Allah: The self-organisation (int/zam) of the Tablîghî Jamâ'at. Oriente Moderno 23: 295-305. [CrossRef]

Reetz, Dietrich. 2006. Sûfî Spirituality Fires Reformist Zeal: The Tablîghî Jamâ'at in Today's India and Pakistan. Archives de Sciences Sociales des Religions 135: 33-51. [CrossRef]

Reetz, Dietrich. 2007. The Deoband Universe: What Makes a Transcultural and Transnational Educational Movement of Islam? Comparative Studies of South Asia, Africa and the Middle East 27: 139-59. [CrossRef] 
Ridgeon, Lloyd Ridgeon. 2017. Reading Sufi History through ādāb: The Perspectives of Sufis, Jawānmardān and Qalandars. In Ethics and Spirituality in Islam: Sufi Adab. Edited by Francesco Chiabotti, Eve Feuillebois-Pierunek, Catherine Mayeur-Jaouen and Luca Patrizi. Leiden: Brill, pp. 379-402.

Rosello, Mireille. 2001. Postcolonial Hospitality: The Immigrant as Guest. Stanford: Stanford University Press.

Rushdie, Salman. 1988. The Satanic Verses. London: Viking.

Rustomji, Nerina. 2010. Early Views of Paradise in Islam. Religion Compass 4: 166-75. [CrossRef]

Schimmel, Annemarie. 1975. Mystical Dimensions of Islam. North Carolina: University of North Carolina Press.

Schimmel, Annemarie. 1978. The Triumphal Sun: A Study of the Works of Jalāloddin Rumi. London: Fine Books.

Sewag, Zulqarnain. 2016. The Intra-Sunni Conflicts in Pakistan. In Faith-Based Violence and Deobandi Militancy in Pakistan. Edited by Jawad Syed, Edwina Pio, Tahir Kamran and Abbas Zaidi. London: Palgrave Macmillan, pp. 313-44.

Shaheed, Farida. 2010. Contested Identities: Gendered Politics, Gendered Religion in Pakistan. Third World Quarterly 31: 851-67. [CrossRef]

Shah-Kazemi, Reza. 2004. From the Spirituality of Jihād to the Ideology of Jihadism. In Faith-Based Violence and Deobandi Militancy in Pakistan. Edited by Jawad Syed, Edwina Pio, Tahir Kamran and Abbas Zaidi. London: Palgrave Macmillan, pp. 119-48.

Shirvani, Hamid. 1985. The Philosophy of Persian Garden Design: The Sufi Tradition. Landscape Journal 4: 23-30. [CrossRef]

Sidat, Haroon. 2018. Between Tradition and Transition: An Islamic Seminary, or Dar al-Uloom, in Modern Britain. Religions 9: 314. [CrossRef]

Sidat, Haroon. 2019. Shedding light on the Modalities of Authority in a Dar al-Uloom, or Religious Seminary, in Britain. Religions 10: 653. [CrossRef]

Siddiqi, Bulbul. 2018. Becoming 'Good Muslim': The Tablighi Jamaat in the UK and Bangladesh. Singapore: Springer.

Sikand, Yoginder S. 1998. The Origins and Growth of the Tablighi Jamaat in Britain. Islam and Christian-Muslim Relations 9: 171-92. [CrossRef]

Sikand, Yoginder S. 2002. Origins and Development of the Tablighi-Jama'at (1920-2000): A Cross-Country Comparative Study. Hyderabad: Sangam Books.

Smith, Trevor Douglas. 2004. 'A Funny Kind of Englishman': Hanif Kureishi's Representations of South Asians in British Cinema. Unpublished Master's thesis, Simon Fraser University, Vancouver, BC, Canada. Available online: file:///C:/Users/esouser/ AppData/Local/Temp/b36827423\%20-1.pdf (accessed on 15 November 2020).

Strothman, Linus. 2016. Islam, Sufism and Everyday Politics of Belonging in South Asia. Edited by Deepra Dandekar and Torsten Tschacher. New York: Routledge, pp. 228-44.

Syed, Jawad. 2016. Barelvi Militancy in Pakistan and Salmaan Taseer's Murder. In Faith-Based Violence and Deobandi Militancy in Pakistan. Edited by Jawad Syed, Edwina Pio, Tahir Kamran and Abbas Zaidi. London: Palgrave Macmillan, pp. $231-71$.

Takim, Liyakat. 2016. Violence and the Deobandi Movement. In Faith-Based Violence and Deobandi Militancy in Pakistan. Edited by Jawad Syed, Edwina Pio, Tahir Kamran and Abbas Zaidi. London: Palgrave Macmillan, pp. 481-504.

Taylor, Charles. 2002. Modern Social Imaginaries. Public Culture 14: 91-124. [CrossRef]

Touseef, Muhammad, and Alexandre Papas. 2019. The History of Sufism in Multan: New Data from the Urdu Tadhkirah Tradition. Islamic Studies 58: 471-501.

Travis, Alan. 1999. Prison Service Gets First Muslim Adviser. The Guardian. September 8. Available online: https://www.theguardian. com/world/1999/sep/08/religion.justice (accessed on 19 August 2020).

Van Bruinessen, Martin. 2009. Sufism, 'Popular' Islam and the Encounter with Modernity. In Islam and modernity: Key issues and debates. Edited by Muhammad Khalid Masud, Armando Salvatore and Martin van Bruinessen. Edinburgh: Edinburgh University Press, pp. 125-57.

Van der Leeuw, Gerardus. 1938. Religion in Essence and Manifestation: A Study in Phenomenology. London: G. Allen \& Unwin. First published 1933.

Van der Veer, Peter. 1994. Religious Nationalism: Hindus and Muslims in India. Berkeley: University of California Press.

Viitamäki, Mikko. 2017. The Delicate Balance: Adab and Mystical States in the Musical Assemblies of Sufis in Medieval India. In Ethics and Spirituality in Islam: Sufi Adab. Edited by Francesco Chiabotti, Eve Feuillebois-Pierunek, Catherine Mayeur-Jaouen and Luca Patrizi. Leiden: Brill, pp. 584-607.

Wahh. 2010. 'Making Music' Live Performance by Hindustani/Flamenco Fusion Group Wahh (Ft. Jay Gandhi-bansuri). YouTube. October 5. Available online: https: / /www.youtube.com/watch?v=m9rX1NvpXTE (accessed on 3 November 2020).

Warsi, Sayeeda. 2017. The Enemy Within: A Tale of Muslim Britain. London: Allen Lane.

Weinstein, Deena. 2013. Rock's Guitar Gods-Avatars of the Sixties. Archiv für Musikwissenschaft 70: 139-54.

Werbner, Pnina. 2004. Theorising Complex Diasporas: Purity and Hybridity in the South Asian Public Sphere in Britain. Journal of Ethnic and Migration Studies 30: 895-911. [CrossRef]

Werbner, Pnina. 2017. The Abstraction of Love: Personal Emotion and Mystical Spirituality in the Life Narrative of a Sufi Devotee. Culture and Religion 18: 165-80. [CrossRef]

Wescoat, James L., Jr., and Joachim Wolschke-Bulmahn, eds. 1996. Mughal Gardens: Sources, Places, Representations, and Prospects. Washington, DC: Dumbarton Oaks Research Library and Collection. 
Westrop, Sam. 2016. Hidden in Plain Sight: Deobandis, Islamism and British Multiculturalism Policy. In Faith-Based Violence and Deobandi Militancy in Pakistan. Edited by Jawad Syed, Edwina Pio, Tahir Kamran and Abbas Zaidi. London: Palgrave Macmillan, pp. 453-80.

Wilkerson, Isabel. 2020a. America's 'Untouchables': The Silent Power of the Caste System. The Guardian. July 28. Available online: https:/ / www.theguardian.com/world/2020/jul/28/untouchables-caste-system-us-race-martin-luther-king-india (accessed on 28 July 2020).

Wilkerson, Isabel. 2020b. Caste: The Lies That Divide Us. London: Allen Lane.

Wood, Philip. 2011. Marriage and Social Boundaries among British Pakistanis. Diaspora: A Journal of Transnational Studies 20: 40-64. [CrossRef]

Wright, Melanie J. 2007a. Re-Viewing My Son the Fanatic (Udayan Prasad, 1997) after 7/7; or, Roots, Routes, and Rhizomes. In The Religious Roots of Contemporary European Identity. Edited by Lucia Fatin and Melanie J Wright. New York: Continuum, pp. 29-39.

Wright, Melanie J. 2007b. My Son the Fanatic. In Religion and Film: An Introduction. Edited by Melanie J. Wright. New York: Palgrave Macmillan, pp. 107-27, 193-96.

Zaman, Muhammad Qasim. 1999. Religious Education and the Rhetoric of Reform: The Madrasa in British India and Pakistan. Comparative Studies in Society an History 41: 294-323.

Zaman, Muhammad Qasim. 2002. The Ulama in Contemporary Islam: Custodians of Change. Princeton: Princeton University Press.

Zaman, Muhammad Qasim. 2018. Islam in Pakistan: A History. Princeton: Princeton University Press. 